\title{
Internal Corporate Investigations and the Truth
}

\author{
Kevin H. Michels
}

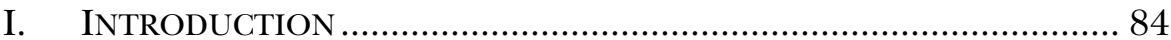

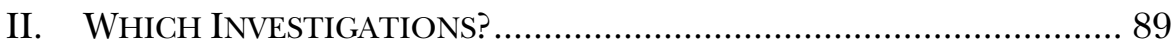

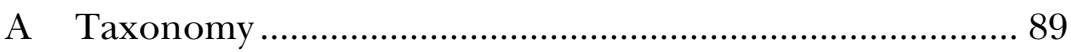

1. The Counseling Investigation ................................... 89

2. The Due Diligence Investigation ................................ 90

3. The Reliance and Duty Investigations .......................... 91

a. Third-Party Reliance .............................................. 91

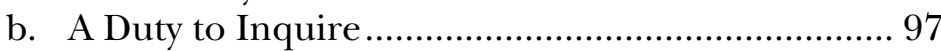

B. Additional Reasons to Satisfy the Truth Standards ......... 100

III. INVESTIGATIONS AND THE TRUTH ........................................... 101

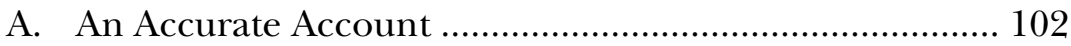

1. Objectivity and Professional Judgment...................... 104

2. Objectivity and Procedure ......................................... 110

B. The Truth Standards: Tools of Accuracy ........................ 111

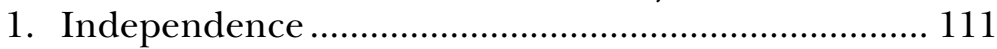

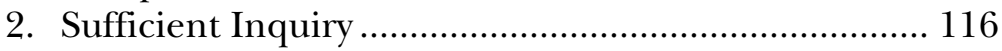

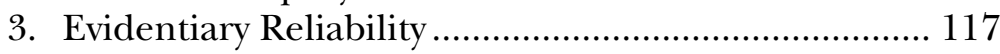

4. Professional Judgment.............................................. 120

C. The Degree of Certainty ................................................ 121

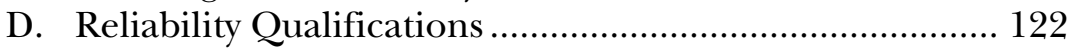

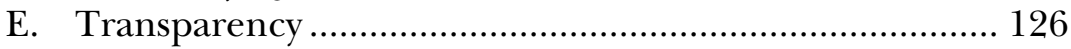

F. The Truth Standards and Negligence ............................ 127

IV. The TRUTH StANDARDS APPLIED ............................................. 129

A. The Retention Structure ................................................. 129

1. The Biasing Interest................................................ 130

2. The Advocacy Conflict.............................................. 133

3. The Sufficient-Inquiry Standard ............................... 135

B. Conducting the Investigation ........................................ 136

1. Scope and Depth.................................................... 136

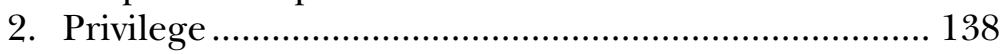

\footnotetext{
* Assistant Professor of Business Law and Ethics, The College of New Jersey. The author wishes to thank Douglas Husak and Kathryn Hockenjos for their excellent comments on drafts of this Article.
} 


\section{INTRODUCTION}

In 2008, nearly half of all United States public companies commissioned outside counsel to conduct at least one internal investigation. ${ }^{1}$ An internal investigation may be triggered by allegations from an employee-whistleblower, a threatened shareholders' derivative action, a request for information from the government, a government investigation, a media investigation, or a civil complaint. ${ }^{2}$ Whatever their source, these allegations present a grave threat to the corporation. If valid, they may lead to significant civil liability and criminal penalties for the company and its principals. Corporations engage counsel to investigate these allegations and rely on counsel's investigative report in shaping corporate policy, in fashioning a response to the allegations, ${ }^{3}$ and in fulfilling their investigation duties under Sarbanes-Oxley and management's duty of care. ${ }^{4}$ In the current wave of corporate scandal, calls for internal investigations of alleged wrongdoing may intensify.

The internal investigation results reverberate well beyond the corporation. Prosecutors-often without resources to replicate the company's investigative effort-may rely on the report in determining whether an offense has occurred, what that offense may be, and whom to charge with criminal wrongdoing. ${ }^{6}$ Moreover, company

${ }^{1}$ Fulbright \& JawOrSki LLP, Fifth ANNuAl Litigation Trends Survey Findings 29 (2008). In addition, one third of private companies conducted internal investigations in 2008. Id at 28; see also Leigh Jones, Call for Internal Probes Growing, NAT'L L.J., Nov. 22, 2004, at 1 (reporting that internal-investigation counsel are a "dreaded necessity" for public companies).

${ }^{2}$ For an extensive list of investigation triggers, see Sarah Helene Duggin, Internal Corporate Investigations: Legal Ethics, Professionalism and the Employee Interview, 2003 Colum. Bus. L. Rev. 859, 884; see also Gideon Mark \& Thomas C. Pearson, Corporate Cooperation During Investigations and Audits, 13 StAn. J.L. Bus. \& FIn. 1, 7-8 (2007) (citing reasons for internal corporate investigations).

${ }^{3}$ See infra Part II.A (discussing reasons for and use of internal investigations).

4 See infra notes 62-68 and accompanying text.

5 See generally Paul L. Lee, Risk Management and the Role of the Board of Directors: Regulatory Expectations and Shareholder Actions, 125 BANKING L.J. 679 (2008) (noting that recent credit crisis will place renewed attention on the role of directors in the management of risk and wrongdoing).

${ }^{6}$ See William S. Laufer, Corporate Prosecution, Cooperation, and the Trading of Favors, 87 IowA L. REv. 643, 664 (2002) (noting "the overwhelming dependence of prosecutors on information and evidence difficult to obtain from complex organizations without incentives, and the limited resource of prosecutors' offices"). 
cooperation by conducting and releasing the results of an internal investigation may reduce criminal penalties. ${ }^{7}$ Government agencies may use the reports in determining whether to impose penalties and other regulatory sanctions. ${ }^{8}$ A court may rely on the results of an investigation when dismissing a shareholder derivative action against the company. ${ }^{9}$ The corporation may publicly release the results, a summary of the results, or the report itself as evidence of the absence of wrongdoing or of the company's resolution of the problem. ${ }^{10}$

Given the extent to which various constituencies rely on the results of internal corporate investigations, a fundamental question is whether the internal investigation and its report are trustworthy. There is reason for concern. While the American legal system has long presumed the clash of adversaries to be the best guarantor of truth, ${ }^{11}$ the investigator stands alone, implicitly asking us to accept her unilateral efforts as trustworthy. The investigator, however, is retained and compensated by the corporation that is the subject of the allegations, raising troubling questions about loyalty, accountability, and conflicting objectives.

The questions are legion. Is the internal investigation team under special truth or reliability standards even if the report harms the

7 See infra note 49 and accompanying text.

8 See generally Report of Investigation Pursuant to Section 21(a) of the Securities Exchange Act of 1934 and Commission Statement on the Relationship of Cooperation to Agency Enforcement Decisions, Exchange Act Release No. 44969 (Oct. 23, 2001) [hereinafter Seaboard Report], available at http://www.sec.gov/litigation/ investreport/34-44969.htm (utilizing a company's audit committee report for assistance in making a determination).

${ }^{9}$ See Kaplan v. Wyatt, 484 A.2d 501, 519-20 (Del. Ch. 1984).

${ }^{10}$ For example, investigative counsel's internal investigation of management's conduct in developing and marketing the drug Vioxx, which largely exonerated Merck management, was posted on the Web sites of both the law firm and Merck, and the report's release was announced in press conferences. In re Vioxx Prod. Liab. Litig., MDL No. 1657, 2007 U.S. Dist. LEXIS 23164 (E.D. La. Mar. 5, 2007) (granting protective order in underlying investigation materials). For an example of the widespread news accounts of the investigative report, see Alex Berenson, Merck Inquiry Backs Conduct over Vioxx, N.Y. Times, Sept. 7, 2006, at C1; John Markoff \& Eric Dash, Apple Panel on Options Backs Chief, N.Y. Times, December 30, 2006, at C1.

${ }^{11}$ E.g., Scontsas v. Citizens Ins. Co., 253 A.2d 831, 833 (N.H. 1969) ("It is the philosophy of the adversary system that the truth will more likely be reached if both sides of the issue are fully presented and that this is more likely to occur if the sides are presented by partisan advocates."). Professor Wigmore famously termed a central element of the adversarial system, cross examination, "the greatest legal engine ever invented for the discovery of truth." JOHN HENRY WigmoRE, EVIDENCE IN TRIALS at Common Law 32 (James H. Chadbourn ed., Little, Brown \& Co. 1974) (1940). For a comparison of adversarial and inquisitorial approaches to justice, see ALvin I. GOLDMAN, KNOWLEDGE IN A SOCIAL WORLD $§ 9.4$ (1999). 
client who undertakes and pays for the investigation? If so, what are these standards? Are all internal investigations subject to these standards, including investigations that are intended to further a representation? If and when special truth standards do attach, how can the attorney's duty to a third party be reconciled with the duties that an attorney owes his client? Do tensions or counter-incentives that inhere in the nature or structure of the investigative process undermine the search for truth? Conversely, are certain structures more likely to enhance reliability? Can the recipient of an investigative report rely on its conclusions when professionals regularly disagree on matters of interpretation?

Despite the considerable literature on internal investigations, commentators and courts have not developed a conceptual understanding of these issues. ${ }^{12}$ This inattention can be traced to a variety of causes. First, in routine transactions and litigation matters, attorneys regularly investigate client facts and information and disclose such information to third parties either directly or in the form of opinion letters. Thus, it is not immediately evident which investigations should be subject to special truth standards. Second, because some statutes require corporations to conduct an independent investigation when certain triggers arise, ${ }^{13}$ practitioners may assume that only investigations conducted pursuant to a such a mandate are sub-

${ }^{12}$ For example, the leading treatise on the subject discusses the importance of independence in an investigation without exploring the more fundamental questions about the truth commitment of an investigation. Michael J. Shepard \& Robert B. Buehler, No Security: Internal Investigations into Violations of the Securities Laws, in INTERNAL CORPORATE InVESTIGATIONS 353, 386-89 (Barry F. McNeil \& Brad D. Brian eds., 3rd ed. 2007). Much of the commentary in this treatise and elsewhere has been directed to when and whether to conduct an internal investigation, how to deal with employee and other witnesses, privilege, and work-product protections, and how and whether to report the results. Id. See generally Robert S. Bennett et al., Internal Investigations and the Defense of Corporations in the Sarbanes-Oxley Era, 62 Bus. LAW. 55 (2006) (offering a useful summary of investigation issues). These are critical questions, but they are best considered in light of the truth commitment that the investigative role entails. Practitioner treatments of the reliability question have offered helpful analyses of court decisions but have not sought to develop a principled account of the basis or significance of the reliability standards or their universality. E.g., Jeffrey M. Kaplan et al., Internal Corporate Investigations in the Post-Enron Era: A Guide to Independence Requirements, in 2 CORPORATE COMPLIANCE 2003 (PLI Corporate Law \& Practice, Course Handbook Series No. B-1366, 2003). An early practitioner effort to identify some of the reliability questions posed by internal investigations is Arthur F. Mathews, Internal Corporate Investigations, 45 OHIO ST. L.J. 655 (1984). An early scholarly treatment is Samuel H. Gruenbaum \& Martin A. Oppenheimer, Special Investigative Counsel: Conflicts and Roles, 33 RuTGERS L. REV. 865 (1981).

${ }^{13}$ For example, the Sarbanes-Oxley Act of 2002 authorizes independent investigations in certain instances but does not define the term with any precision. Pub. L. No. 107-204, § 301(5), 116 Stat. 745, 776 (2002). See discussion infra notes 61-66. 
ject to reliability standards. ${ }^{14}$ They also assume that the standards referenced by such statutes or court opinions are the only standards that an investigation need satisfy. Third, if there are obligations beyond these statutory or investigation-specific requirements, it is not clear what they are and from what sources of law they derive. ${ }^{15}$ Fourth, because there is so much discretion involved in the investigation, truth obligations might be perceived as quixotic. Fifth, because practitioners know that an investigation must be credible if it is to be of value to the party that receives the results, it is a short step to the assumption that the principal trustworthiness constraint on an investigation is one of perception rather than obligation. Finally, some may assume that any constraints on the reliability of the investigation can be solved by disclosure and disclaimers to the recipient of the report, an assumption that may not withstand scrutiny.

Given the number of investigations that corporations conduct each year and the weight that company directors, prosecutors, regulatory authorities, the courts, the public, and the media afford the results, it is time for a systematic inquiry into the nature and extent of the truth commitment of investigative counsel. This Article will seek to develop a principled account of when investigative counsel are subject to special truth obligations, what those obligations are, how they can be understood in a client setting, and what they entail for the structure and conduct of an internal corporate investigation and for disclosure of the results. ${ }^{16}$

Part II of this Article examines the threshold questions. It develops a taxonomy of investigations based on their varying rationales that will allow us to identify which investigations should be subject to special truth standards. In particular, Part II identifies two investigation types that pose special concerns and warrant imposition of truth standards: (1) reliance investigations, which are investigations that will be shared with third parties including the government, the courts, and the public, and (2) duty investigations, which are investigations in furtherance of a legal duty of inquiry. Part II will explain why these two investigation types pose special truth concerns under, respectively, the attorney-ethics rules that govern the practice of law in nearly every American jurisdiction and the special corporation law

\footnotetext{
${ }^{14}$ For a discussion of the variety of reasons to conduct an internal investigation, only some of which are statutory, see infra Part II.A.

${ }_{15}$ For a discussion of these sources, see infra Part II.A.3.

${ }^{16}$ Although our emphasis here is on the role of the internal investigator, we will examine the corporation's truth obligations to the extent they shape the investigator's truth commitment.
} 
and statutory-investigation duties that require inquiry when allegations of wrongdoing arise. Part II will conclude with a discussion of why corporations may insist on satisfaction of the truth standards in other internal investigations conducted in response to allegations of wrongdoing.

Part III will address this Article's core objective, the identification and analysis of the truth standards that must be satisfied in a reliance or duty investigation. The Article will contend that an accurate account must be the substantive goal of any reliance or duty investigation. This notion raises fundamental questions about the objectivity of law and whether there can be a "correct" or "accurate account" in an internal investigation. To explore these questions, Part III will look to philosophy, jurisprudence, and historiography-all disciplines that have struggled with basic questions about whether subjectivity irretrievably clouds our search for truth. Insights from these disciplines will help refine our understanding of accuracy in the investigation setting and explain why an array of other truth standards follows from a commitment to accuracy. ${ }^{17}$ Part III will explain why four truth standards-independence, sufficient inquiry, evidentiary reliability, and professional judgment-must be satisfied in order to provide an accurate account in a reliance or duty investigation. Part III will also examine the degree of certainty an investigator should claim for her conclusions, why a listing of disclaimers is insufficient counterpoise to an investigator's conclusions, why a detailed analysis should accompany the investigator's conclusions, and how the truth standards can refine our understanding of an investigator's tort duties.

Part IV will apply the truth standards to selected aspects of the three main phases of an internal investigation: retention, the investigation itself, and the reporting. The standards will lead us to question certain client commitments undertaken by investigative counsel that can undermine the investigation role.

17 The fusion of the theoretical and practical in this Article owes much to two contributions on the calling and methodology of legal scholarship. The first is Judge Harry T. Edwards's seminal plea for prescriptive legal scholarship that "analyzes the law and the legal system with an aim to instruct attorneys in their consideration of legal problems; to guide judges and other decision-makers in their resolution of legal disputes." Harry T. Edwards, The Growing Disjunction Between Legal Education and the Legal Profession, 91 Mich. L. REv. 34, 42-43 (1992). The second is Jean Braucher's contention, presented in connection with her review of Jay Feinman's excellent treatise on economic negligence, that the analysis of the problems confronting lawyers and judges is stronger and more sophisticated when it is grounded in legal theory. Jean Braucher, Economic Negligence: Liability of Professionals and Businesses to Third Parties for Economic Loss, 51 BUS. LAW. 795, 799 (1996). 
Part V will conclude by revisiting the questions raised in this introduction and by offering some general considerations about the principles developed herein and their value for corporations, investigative counsel, and recipients of investigative reports.

\section{WHICH INVESTIGATIONS?}

In this Part, the goal is to identify which internal investigations warrant the imposition of special truth standards. To shed light on that question, this Article will first develop a taxonomy of investigation types based on how the investigation information will be used. This taxonomy should help analyze which of these investigation roles (if any) requires special attention from a truth or reliability perspective.

\section{A Taxonomy}

1. The Counseling Investigation

Attorneys conduct investigations of corporate clients for a variety of reasons. Not all of these investigations pose truth and reliability concerns that warrant the imposition of special standards. For example, attorneys routinely investigate the client in order to learn information that will advance a litigation or counseling objective for the corporation. This first category, which we will term a counseling investigation, is marked by the consonance of interest between attorney and client. The investigation is not undertaken to fulfill a corporate management duty to investigate and is often used to assist counsel in advising the client. ${ }^{18}$ When information learned in a counseling investigation is disclosed to third parties-for example, in litigation discovery or in the course of a negotiation-it does not purport to be backed by counsel's investigation. As a result, the counseling investigation does not implicate truth concerns that differ from any standard representation. The attorney-ethics rules and standard of care that govern every representation provide adequate protection to

${ }^{18}$ The counseling investigation is often conducted with an eye toward preserving attorney-client privilege and attorney-work product protections in the investigation results and underlying materials. For the privilege protections to attach, the communications with counsel must, inter alia, have been to obtain legal advice. Upjohn Co. v. United States, 449 U.S. 383, 394-96 (1981) (upholding privilege and work-product protections in internal investigation into allegations that company employees engaged in bribery). The seminal definition of "work product" in Hickman $v$. Taylor, 329 U.S. 495, 508 (1947) is refined and codified in FED R. CIV. P. 26(b) (3) (B), which, absent substantial need, protects the "mental impressions, conclusions, opinions, or legal theories of a party's attorney ... concerning the litigation." 
third party and client, respectively, in this setting. ${ }^{19}$ The attorney must also report candidly and with independent professional judgment to his client. ${ }^{20}$

\section{The Due Diligence Investigation}

A second category of investigation, which we will call a due diligence investigation, is typically conducted by counsel to ground her representations to a third party. ${ }^{21}$ The archetypal example is the investigation undertaken to support a representation set forth in an opinion letter that counsel delivers to a third party in connection with a transaction. ${ }^{22}$ For example, in a business transaction, an attorney may be asked to opine on the good standing of the client, ${ }^{23}$ the validity of the transaction, ${ }^{24}$ whether the security provided is valid, ${ }^{25}$ or whether the transaction is subject to a tax exemption. ${ }^{26}$

The due diligence investigation poses fewer truth and reliability risks than the reliance and duty investigations considered in Part

${ }^{19}$ As in every representation, the attorney must not, for example, make a knowing misstatement of material fact to a third party, MODEL RULES OF PROF'L CONDUCT R. 4.1 (2007), and must perform in accordance with the duty of care, RONALD E. MALLEN \& JeFFREy M. SMith, Legal MALPRACTICE $§ 8.2$ (2007 ed.).

${ }^{20}$ Model Rules of Prof'L Conduct R. 2.1.

${ }^{21}$ See ABA Comm. on Ethics and Prof'l Responsibility, Formal Op. 346 (1982), reprinted in 68 A.B.A. J. 471, 472 (1982) (discussing ethical obligations for opinion letters relating to tax shelters).

${ }^{22}$ Jonathan C. Lipson, Price, Path, Ev Pride: Third-Party Closing Opinion Practice Among U.S. Lawyers (A Preliminary Investigation), 3 Berkeley BuS. L.J. 59, 62 (2005) (noting that third-party closing opinions are a "fixture of the American legal scene[]") (citing Donald W. Glazer et AL., Glazer and Fitzgibbon on Legal OPINIONS IN BUSINESS TRANSACTIONS § 1.1 (2d ed. 2001)). Additionally, there are hundreds of third party legal opinions being delivered each week. Id. (quoting Comm. on Legal Opinions, ABA Section of Bus. Law, Law Office Opinion Practices, 60 Bus. LAW. 327 (2004)).

${ }^{23}$ E.g., Zimmerman v. Dan Kamphausen Co., 971 P.2d 236, 238 (Colo. App. 1998) (involving a law firm opinion letter stating that a partnership was properly constituted and had the legal power to execute a guaranty and perform its obligations thereunder, and that the signatory was authorized to sign a guaranty on behalf of the partnership).

${ }^{24}$ E.g., Prudential Ins. Co. of Am. v. Dewey, Ballantine, Bushby, Palmer \& Wood, 605 N.E.2d 318, 323 (N.Y. 1992) (involving an opinion letter offering assurances to the creditor about the borrower's business, that the loan documents were valid, properly authorized and enforceable, and that the terms did not violate an obligation of the borrower).

${ }^{25}$ E.g., Mark Twain Kansas City Bank v. Jackson, Brouillette, Pohl \& Kirley, P.C., 912 S.W.2d 536, 537 (Mo. App. 1995) ("[s]ecurity documents constituted valid, binding and enforceable obligations").

${ }^{26}$ E.g., Weiss v. SEC, 468 F.3d 849, 854 (D.C. Cir. 2006) (involving opinion letter counsel issued to investors concerning tax-exempt status of bonds). 
II.A.3. The representations in transaction opinions are precise, narrowly formulated facts or legal conclusions, designed to satisfy certain conditions precedent to a transaction. The comparatively focused and verifiable representations in an opinion letter render viable recovery for negligent misstatements. ${ }^{27}$ Moreover, the risks of a conflict between attorney and client are comparatively modest in the opinion setting because counsel and client have opportunities to cure deficiencies before the opinion is issued.

\section{The Reliance and Duty Investigations}

Our third category, which consists of what we will call reliance and duty investigations, warrants the imposition of special truth and reliability standards. The internal corporate investigation considered here is typically triggered by allegations of corporate wrongdoing. While commentators often describe this trigger, they have not considered why the investigation in response to an allegation of wrongdoing often warrants imposition of special standards regarding the truth and reliability of the investigation. ${ }^{28}$ First, corporations often have reason to share the findings of an internal investigation into allegations of wrongdoing-both incriminating and exculpatory-with third parties. Second, allegations of wrongdoing often implicate a company's legal duty to learn the truth of the allegation. We will consider each of these instances next.

\section{a. Third-Party Reliance}

The corporation may choose to share internal investigation results with the government, the public, and the courts, and thereby invite them to rely on the results. The client and the third-party recipient both have a substantial interest in the outcome of the internal investigation, which is typically an inquiry into whether the corporation or its agents have committed wrongdoing. The potential for conflict between the client and the third party presents such a grave risk to the integrity of the investigation that it is addressed by the attorney-ethics rules, although few commentators and practitioners have looked to the attorney-ethics rules in analyzing the responsibilities of counsel in an internal investigation. ${ }^{29}$

${ }^{27}$ See, e.g., Kline v. First W. Gov't Sec., Inc., 24 F.3d 480, 481 (3d Cir. 1994); In re Enron Corp. Sec., Derivative \& “ERISA” Litig., 511 F. Supp. 2d 742, 751-52, 769 (S.D. Tex. 2005).

${ }^{28}$ See, e.g., Duggin, supra note 2.

${ }^{29}$ For example, the leading volume on internal investigations makes no mention of the attorney-ethics rules generally, or MOdel Rules OF PROF'L CONDUCT R. 2.3 spe- 
The Model Rules of Professional Conduct, ${ }^{30}$ adopted with variations in nearly every state, ${ }^{31}$ impose a comprehensive set of obligations on attorneys." Model Rule 2.3, entitled "Evaluation for Use by Third Persons," allows an attorney with client consent to conduct an "evaluation of a matter affecting a client for the use of someone other than the client." ${ }^{, 33}$ Under the Rule, a lawyer may conduct an evaluation if "the lawyer reasonably believes that making the evaluation is compatible with other aspects of the lawyer's relationship with the client.", Part III will consider the significance of this Rule in developing truth standards that control an internal investigation. The threshold concern, however, is which investigative efforts are controlled by the Rule.

Model Rule 2.3(a) can be parsed into three elements. ${ }^{35}$ First, the attorney must undertake an "evaluation." must concern "a matter affecting the client." ${ }^{37}$ Third, the evaluation

cifically. INTERNAL CORPORATE INVESTIGATIONS, supra note 12. Even the penetrating analysis of the Enron investigation and the conflicts faced by investigative counsel offered by Professor Cramton makes no reference to MODEL RULES OF PROF'L Conduct R. 2.3(a). See generally Roger C. Cramton, Enron and the Corporate Lawyer: A Primer on Legal and Ethical Issues, 58 Bus. LAW. 143 (2002).

${ }^{30}$ The ABA first promulgated the Model Rules in 1983, and they have been amended frequently since, including substantial revisions in 2002, based on the recommendations of the ABA Commission on Evaluation of the Rules of Professional Conduct, chaired by Chief Justice E. Norman Veasey. Model Rules of Prof'L CONDUCT, Chair's Introduction (2007).

${ }^{31}$ Forty-nine states have adopted some version of the Model Rules of Professional Conduct, often with amendments. See ABA/BNA Lawyers' Manual on Professional CONDUCT $\S 1: 3$ (2009) (listing ethics rules adopted in each state) [hereinafter LAWYERS' MANUAL]. In 2009, New York and Maine adopted the Rules of Professional Conduct, superseding the Code of Professional Responsibility. Id.; ME. RulEs OF Prof'L CONDUCT pmbl. (2009). California is considering adoption of the Model Rules. Comm'n for the Revision of the Rules of Prof'l Conduct, The State Bar of Cal., http://calbar.ca.gov/state/calbar/calbar_generic.jsp?cid=10129\&id=1100 (last visited Feb. 25, 2010).

${ }^{32}$ In re Greenberg, 714 A.2d 243, 250 (N.J. 1998) (noting that ethics rules provide "a road map for the conduct of attorneys to guide them in their relationships with their clients, other attorneys, the courts, and the public"); MODEL RULES OF Prof'L Conduct, Scope, at [19] ("Failure to comply with an obligation or prohibition imposed by a Rule is a basis for invoking the disciplinary process."); LAWYERS' MANUAL, supra note 31 at $\$$ 01:101-195; John Leubsdorf, Legal Malpractice and Professional Responsibility, 48 RUTGERS L. REV. 101, 118 (1995) ("Not only do these rules reflect a broad consensus among courts and bar committees about how lawyers should behave, they also constitute law that lawyers must obey.”).

33 Model Rules of Prof'L Conduct R. 2.3(a).

${ }^{34} I d$.

${ }^{35}$ See id.

${ }^{36} I d$.

${ }^{37} I d$. 
must be for "the use of someone other than the client." investigation is intended to assess some aspect of the client's affairs, and thus it undoubtedly qualifies as an "evaluation" under the first element of Model Rule 2.3(a).

The second element of the Rule seeks to distinguish investigations for the client's own use from investigations for third parties. ${ }^{40}$ As the comments note, the rule applies to attorneys who are retained by the client "whose affairs are being examined." analysis of the property title of the seller for a client buyer would not be within the scope of the rule. ${ }^{42}$ Nevertheless, this second element of the rule is satisfied by the internal corporate investigation because the corporation retains the investigator to examine and report to a third party on an allegation of wrongdoing by the corporation. The corporation is, as the Rule contemplates, both the subject of the investigation and the client of the investigating attorney.

The third element of Model Rule 2.3(a) looks to the purpose of the evaluative effort. ${ }^{43}$ The Rule applies only to evaluations for "the use of someone other than the client." An understanding of this element requires fusion of the evaluation and use elements. The element is not satisfied simply by disclosure to a third party of information that is learned in an internal investigation. Rather, the investigator must represent or imply that the information disclosed is based on an "evaluation," which as noted above includes an internal investigation. ${ }^{45}$ The disclosure of information to a third party without any claims about its provenance does not implicate Model Rule 2.3. Thus, a corporation that conducts an internal investigation, but wishes to share only selected results with a third party, is not bound by the strictures of Model Rule 2.3 if it does not claim or imply that the information disclosed is the result of an internal investigation. Model Rule 2.3 is triggered, however, when the information disclosed, even

38 Id.

39 This reading is affirmed by the RESTATEMENT (THIRD) OF THE LAW GOVERNING LAWYERS $\$ 95 \mathrm{cmt}$. a (2000), which closely tracks Model Rule 2.3, and notes that internal corporate investigations are subject to the Rule.

40 See Model Rules of Prof'L Conduct R. 2.3(a).

Id. at cmt. 2.

${ }^{42}$ Id.

${ }^{43}$ See id. at R. 2.3(a).

${ }^{44}$ Id. at cmt. 2.

45 See supra note 39 and accompanying text. 
if only a summary, is expressly or impliedly represented as being based on an internal investigation.

To ground our inquiry into the reach of Model Rule 2.3, suppose that a corporation commissions a law firm to conduct an internal investigation in response to an accusation of company wrongdoing. If the report exonerates the company, the company will likely hasten to dispel the perception of wrongdoing to the shareholders and the public. Instead of simply declaring its innocence, the company will announce the findings of the internal investigation conducted by investigative counsel. ${ }^{47}$ The corporation's release of investigative findings to the public would trigger Model Rule 2.3 because the information is portrayed as investigative findings to the public, which will "use" the findings.

If, in our example, the internal investigation found wrongdoing, the company still has ample incentive to disclose it to government authorities in furtherance of statutory and regulatory provisions that encourage or reward self-investigation and reporting of wrongdoing. For example, under the U.S. Sentencing Guidelines, a company that self-reports wrongdoing before a government investigation is commenced receives a five-point reduction in the sentencing calculation. $^{49}$ The SEC likewise reduces penalties for companies that conduct a thorough investigation and report the results to the Commission and the public. ${ }^{50}$ Other government agencies encourage

${ }^{46}$ For a discussion of truth standards and report summaries, see infra Parts III.F and IV.C. In addition, MOdEl Rules OF Prof'L CONDUCT R. 4.1(a) bans counsel from knowingly making false statements to a third party.

${ }^{47}$ The reputation of a company ranks among its most valuable assets and a company therefore has considerable incentive to release investigation results to quell or at least manage public concern. See In re Kidder, Peabody Sec. Litig., 168 F.R.D. 459, 466 (S.D.N.Y 1996) (internal investigation conducted because "Kidder's unique public profile and its vulnerability to the ebb and flow of market opinion and the predations of its competitors made it urgent that the internal investigation be well publicized and viewed as the inquiry of an 'independent' and incorruptible outsider"); supra note 10.

${ }^{48}$ Even though the public may not take legal action based on the contents of the report, their receipt should best be understood as a "use" within the reach of MODEL RULES OF PROF'L CONDUCT R. 2.3 because the disclosure is intended to shape perception of the company's behavior.

${ }^{49}$ U.S. Sentencing Guidelines Manual $§ 8 \mathrm{C} 2.5(\mathrm{~g})(1)$ (2008). Of course, the disclosure is not without risk. "[A]lthough the disclosure might benefit the company's position in settlement negotiations with the government, it can also provide the government with a 'roadmap' to proceed with an action if it decides to do so, and will certainly supply ammunition to third-party private litigants." Alexandra A.E. Shapiro, Ethics and Best Practices in Internal Investigations, in CORPORATE COMPLIANCE 2007 (PLI Corp. L. \& Prac., Course Handbook Series No. B-1366, 2007).

${ }^{50}$ Seaboard Report, supra note 8. 
and reward the corporation's self-reporting of wrongdoing. ${ }^{51}$ Model Rule 2.3 would apply in each of these instances if the company disclosure is represented to be findings of an internal investigation. Companies have strong incentive to share all of the investigation results, rather than selected information without reference to its provenance, to gain additional credit for cooperation and thereby reduce penalties. $^{52}$

In practice, these incentives to disclose information to the government as investigation results are even greater than the U.S. Sentencing Guidelines and department and agency policies suggest on their face. Constrained by limited budgets and resources, prosecutors and regulatory agencies have additional reason to rely on the results of internal corporate investigations in determining whether to pursue criminal or regulatory sanctions against the corporation and its employees. ${ }^{53}$

${ }^{51}$ Corporations and individuals reporting their involvement in antitrust violations may receive immunity from the DOJ's Antitrust Division under its leniency program, insulating successful applicants from criminal fines and imprisonment. See Dep't of Justice (Antitrust Division) Corporate Leniency Policy (Aug. 10, 1993), available at http://www.usdoj.gov/atr/public/guidelines/0091.pdf. The Environmental Protection Agency is less likely to pursue criminal enforcement against companies that self-report. See Incentives for Self-Policing: Discovery, Disclosure, Correction and Prevention of Violations, 60 Fed Reg. 66,706, 66,706 (Dec. 22, 1995). Defense contractors that self-report misconduct may avoid debarment and reduce prospects for criminal prosecution. See generally Inspector General, DeP'T of Def., Voluntary Disclosure Program: A Description of the Process (Apr. 23, 1990), available at http://www.dodig.mil/IGInformation/archives/vdguidelines.pdf. The New York Stock Exchange rewards cooperation by reducing sanctions, charges or not pursuing criminal prosecution. See NYSE, Inc., Information Memorandum No. 05-65 (Sept. 14, 2005), available at http://apps.nyse.com/commdata/PubInfoMemos.nsf/ AllPublishedInfoMemosNyseCom/85256FCB005E19E88525707C004C6DE0/

\$FILE/Microsoft\%20Word\%20-\%20Document\%20in\%2005-65.pdf.

${ }^{52}$ See Seaboard Report, supra note 8 (citing as factor in determining extent whether "the company produce[d] a thorough and probing written report detailing the findings of its review"). "Timely and voluntary disclosure of wrongdoing" is also considered by federal prosecutors in deciding whether to bring criminal charges against a corporation. Memorandum of Paul J. McNulty, Deputy Attorney General, to Heads of Departmental Components, U.S. Attorneys 4 (Dec. 12, 2006), available at http://www.usdoj.gov/dag/speeches/2006/mcnulty_memo.pdf [hereinafter McNulty Memorandum]. Although waiver of the attorney-client privilege is not a condition of cooperation, "the disclosure of privileged information may be critical in enabling the government to evaluate the accuracy and completeness of the company's voluntary disclosure." Id. at 8.

${ }^{53}$ See William R. McLucas et al., The Decline of Attorney Client Privilege in the Corporate Setting, 96 J. CRIM. L. \& CRIMINOLOGY 621, 639 n.69 (2006) (arguing that government effectively outsources investigation costs to the corporation, which fears graver sanctions if misconduct is discovered and the company had not investigated); $c f$. Laufer, supra note 7, at 646 (noting that with limited government resources and other 
Corporations may also deliver investigative reports to the court in response to notice of a shareholder derivative claim filed against the corporation or in support of a motion to dismiss such a lawsuit. ${ }^{54}$ When a corporation receives a demand to initiate a derivative action, the board's decision to decline such a demand will be afforded considerable deference absent evidence that the board acted without due care, in bad faith, or in self-interest. ${ }^{55}$ Even when the shareholder makes no demand on the corporation prior to filing the derivative action, Delaware law permits the corporation to move to dismiss the action based in part on a good-faith internal investigation conducted at the direction of an independent committee of the board. ${ }^{56}$ A reliable internal investigation is an important element in defending the board's decision not to institute such a claim or to dismiss a claim once brought, although the court's assessment of the investigation's reliability in the shareholder-derivative setting is typically more ad hoc than systematic. ${ }^{57}$ Although courts have not cited Rule 2.3(a) in the shareholder-derivative setting, the Rule applies to investigative reports delivered to courts because they too are "third parties" under the Rule.

Rule 2.3 applies to both attorney opinion letters, which are conducted in furtherance of a due diligence investigation, and to the reliance investigation because both result in reports delivered to third parties. ${ }^{58}$ Truth and reliability concerns, however, are far greater in the reliance investigation for several reasons. First, as noted above, the reliance investigation is typically triggered by allegations of company wrongdoing, ${ }^{59}$ an issue about which the corporation and the

enforcement burdens, "it is little wonder that the government often exchanges leniency for conciliatory post-offense behavior")

${ }^{54}$ In a shareholder derivative claim, a shareholder brings an action on behalf of the corporation against a third party, often the corporation's management, when the corporation has refused or failed to do so. The shareholder must typically first make a demand on the corporation to bring the action, because "it is the company's cause of action." Antony Page, Unconscious Bias and the Limits of Director Independence, 2009 U. ILL. L. REV. 237, 244

${ }_{55}$ See, e.g., Citron v. Fairchild Camera \& Instrument Corp., 569 A.2d 53, 64 (Del. 1989)

${ }^{56}$ See Kaplan v. Wyatt, 484 A.2d 501, 507 (Del. Ch. 1984).

57 See, e.g., Halpert Enters., Inc. v. Harrison, No. 06-Civ-2331(HB), 2007 WL 486561, at $* 5$ (S.D.N.Y. Feb. 14, 2007) (dismissing action and citing five-month internal investigation by an independent law firm, with dozens of interviews, extensive document review, and a lengthy report).

58 Cf. RESTATEMENT (THIRD) OF THE LAW GOVERNING LAWYERS $\$ 95 \mathrm{cmt}$. a (2000). Rule 2.3 applies to attorney opinion letters as well. See Model Rules OF Prof'L Conduct R. 2.3(a) (2007).

${ }_{59}$ See supra note 2 and accompanying text. 
third party have a substantial and often conflicting interest. Second, investigative findings and analysis are not akin to the precise, verifiable representations offered in an opinion letter, but instead require the exercise of judgment and discretion with respect to the nature and extent of the investigation, evaluations of credibility, and interpretation and application of legal standards to a complicated matrix of facts. Thus, opinion letters are subject to checks and balances that are impracticable in the internal investigation context, including liability for misstatements. Third, the internal investigation is a historical exercise; wrongdoing discovered in an internal investigation cannot be "cured" by investigative counsel prior to issuance of a report, and the disclosure of wrongdoing contained in the report may result in severe sanctions for the corporation.

Thus, at least one class of investigations, reliance investigations, poses special truth concerns not implicated by the representation or due diligence investigation. The concern is so great, in fact, that Rule 2.3 allows counsel to perform such an investigation only if her investigative role is reasonably compatible with the investigator's client role. $^{60}$ Part III will consider what this standard signifies for the truth commitment of investigative counsel.

b. A Duty to Inquire

The second category of internal investigations that poses special concerns about truth and reliability is that which is conducted in furtherance of the legal requirement of the corporation to inquire or keep informed ("duty investigation"). For example, the SarbanesOxley Act of 2002 ("Sarbanes-Oxley") requires publicly traded companies to undertake an inquiry in certain circumstances. ${ }^{61}$ If an attorney discovers evidence of the company's "material violation of securities law or breach of fiduciary duty or similar violation," the lawyer must report it to the company's chief legal officer or both the chief legal officer and the chief executive officer." "The chief legal officer ... shall cause such inquiry into the evidence of a material violation as he or she reasonably believes is appropriate to determine whether the material violation described in the report has occurred,

60 See Model Rules of Prof'L Conduct R. 2.3(a).

${ }^{61}$ Sarbanes-Oxley Act of 2002, Pub. L. No. 107-204, § 301, 116 Stat. 745, 775-76 (2002).

${ }^{62} I d . \S 307$ (requiring attorney to report to the board of directors or other committee in the absence of an "appropriate response"); see also 17 C.F.R. \$205.2(e) (2009) (describing nature of knowledge that constitutes evidence of material violation). 
is ongoing, or is about to occur" and cause the company to "adopt an appropriate response." ${ }^{63}$

Thus, when the chief legal officer is confronted with information suggesting particular types of wrongdoing, Sarbanes-Oxley requires a reasonable inquiry into the alleged wrongdoing. ${ }^{64}$ When the chief legal officer retains counsel to fulfill that obligation, counsel's investigation and report must be reliable if it is to satisfy the corporation's reasonable-investigation requirement. In addition, investigations under Sarbanes-Oxley are often conducted by the audit committee of the board of directors in furtherance of its longstanding role in monitoring compliance issues; these roles have been enhanced under Sarbanes-Oxley. ${ }^{65}$ The Act also provides that the audit committee of publicly traded companies "shall have the authority to engage independent counsel and other advisors, as it determines necessary to carry out its duties." ${ }^{66}$ With its emphasis on reasonable and indepen-

6317 C.F.R. $\$ 205.3$ (b) (2) (2009). If the attorney does not believe that the response is appropriate, the attorney must then report the material violation to the audit committee of the board of directors or to a committee of independent directors or to the entire board of directors. $I d$. $\S 205.3$ (b) (3) (i). Alternatively, the attorney can report such concerns to a qualified legal compliance committee, assuming the corporation had already established such committee. Id. § 205.3(b) (2). After such reporting, the attorney need not evaluate the response or report further. Id. $\S$ 205.3(b) (8). See generally William H. Volz \& Vahe Tazian, The Role of Attorneys Under Sarbanes-Oxley: The Qualified Legal Compliance Committee as Facilitator of Corporate Integrity, 43 Aм. Bus. L.J. 439 (2006).

${ }^{64}$ See Shepard \& Buehler, supra note 12, at 372 ("[I] t would be hard for any recipient to formulate an 'appropriate response' without learning the facts through an investigation of some kind.")

${ }_{65}$ See Sarbanes-Oxley Act of 2002, Pub. L. No. 107-204, § $301(\mathrm{~m})$ (4), 116 Stat. 745,776 (2002); Bennett et al., supra note 12, at 61 (audit committee control of Sarbanes-Oxley investigations is now "de rigueur").

${ }^{66}$ Sarbanes-Oxley Act of 2002; see also Cynthia A. Glassman, Comm'r, U.S. Sec. \& Exch. Comm'n, Remarks Before the European Corporate Governance Summit: An SEC Commissioner's View: The Post-Sarbanes-Oxley Environment for Foreign Issuers (Mar. 2, 2005), http://www.sec.gov/news/speech/spch030205cag.htm (encouraging that investigations that are independent "in definition as well as spirit"). The stock exchanges have adopted similar investigative rules. See, e.g., NYSE, Inc., Rule 342.21 (2007) (requiring corporation to conduct internal investigation into any trade that appears to have violated the Securities Exchange Act of 1934, the rules promulgated thereunder, and the "rules of the Exchange prohibiting insider trading and manipulative and deceptive devices"). Internal investigations may also be triggered by an auditor's discovery of company wrongdoing. See 15 U.S.C. $\S 78$ j$l(\mathrm{~b})(1)(\mathrm{B})$ (2006). Under Section 10A of the Private Securities Litigation Reform Act of 1995, an auditor who discovers "information "indicating that an illegal act" has occurred must inform management and the audit committee. Id. If the company does not undertake "appropriate remedial actions," which often includes an internal investigation, the auditor must report to the board of directors, which must immediately inform the SEC. Id. 
dent inquiry, Sarbanes-Oxley has more than evinced a concern about reliability in internal investigations conducted under its provisions.

Another source of a duty to investigate can be implied from the duty of care imposed by corporate law. The duty of care requires directors to keep reasonably informed and to implement systems to monitor legal compliance. ${ }^{67}$ When an allegation of wrongdoing is lodged against the corporation or its agents, management may engage counsel to investigate the facts and analyze their legal significance in order to gain information sufficient to fulfill its duty of care. ${ }^{68}$ Again, the insistence on a reasonable inquiry suggests that an internal investigation intended to satisfy the duty of care must be sensitive to concerns about reliability. ${ }^{69}$ Moreover, the attorney-ethics rules require the attorney to advise his client with candor and independent professional judgment, ${ }^{70}$ a standard that reinforces the obligations of counsel to develop a reliable investigative account for the client.

Some investigations may implicate both duty and reliance concerns. For example, corporations might commission internal investigations to fulfill a duty to investigate charges of employment-related wrongdoing, including allegations of sexual harassment. "When de-

${ }^{67}$ See In re Caremark Int'l Inc. Derivative Litig., 698 A.2d 959, 970 (Del. Ch. 1996) (noting that failure to investigate charges may lead to allegation that corporation recklessly ignored the concern); Duggin, supra note 2, at 882 (noting that case establishes liability of directors "for failing to monitor their organization's compliance with legal obligations").

${ }^{68}$ See 1 Am. LaW Inst., Principles of Corporate Governance: Analysis \& RECOMMENDATIONS $\$ 4.01$ (a) (1) (2008) (noting that the duty of care "includes the obligation to make, or cause to be made, an inquiry when, but only when, the circumstances would alert a reasonable director or officer to the need therefor").

${ }^{69}$ Some statutes or rules require the reporting of information but do not require that the corporation conduct an inquiry or investigation. See, e.g., Anti-Kickback Enforcement Act of 1986, 41 U.S.C. $\$ 57$ (2006) (requiring a written report by government contractors if they have reason to believe a kickback has been given between contracting parties); Medicare Fraud Reporting Act, 42 U.S.C. § 1320a-7b(a)(3) (2006) (imposing criminal penalties for concealing or failing to disclose an "event with an intent fraudulently to secure such benefit or payment either in a greater amount or quantity than is due or when no such benefit or payment is authorized"); NYSE, Inc., Rule 351(a)(1) (2007) (requiring disclosure of certain employee disciplinary matters). These statutes and rules arguably do not justify imposition of the truth standards developed in Part III on an investigation, even one that is conducted to determine whether there is information that must be reported under the statute. Instead, these are better understood as furthering an enforcement objective, such as the disclosure of information that is known to the corporation absent some evidence that a particular statute was designed to mandate monitoring or procedures to ensure discovery of the information. As this Article will discuss infra Part II.B, however, even when the truth standards are not mandated, companies would nonetheless do well to insist that investigative counsel satisfy them.

${ }^{70}$ Model Rules of Prof'L Conduct R. 2.1. (2007). 
termining the adequacy and effectiveness of an employer's response to a hostile environment claim, courts have considered 'whether the employer investigated the alleged acts of harassment and the type of investigation the employer conducted." "71 Courts will inquire into the reasonableness and sufficiency of an internal investigation in determining whether it is a sufficient employer response to defeat employer liability. $^{72}$ Whether viewed as a duty or reliance investigation, it is clear that the reliability of the internal investigation remains a critical concern.

\section{B. Additional Reasons to Satisfy the Truth Standards}

The taxonomy of investigation types has allowed us to identify with some precision the types of investigations-reliance and duty investigations - that warrant the imposition of truth standards. Part III will develop the truth standards that must be satisfied by such investigations. Before turning to this question, we should consider the practical and prudential reasons why corporations should comply with the truth standards even when not required to do so.

First, corporations may conduct an internal investigation without determining in advance how they will use the results. Because an investigation that does not satisfy the truth standards may not satisfy the client's duty of inquiry or be worthy of reliance by a third party, ${ }^{73}$ a corporation can best preserve the option of such disclosure or reliance by conducting an investigation in accordance with the truth standards from the outset. The internal investigation is a substantial undertaking, ${ }^{74}$ and to maximize its use and value, the corporation has an overwhelming incentive to insist on compliance with the truth standards in any investigation triggered by an allegation of wrongdoing. $^{75}$ Second, an accurate and trustworthy account will uncover

${ }^{71}$ Harding v. Dana Transp., Inc., 914 F. Supp. 1084, 1094 (D.N.J. 1996) (quoting Giordano v. William Paterson Coll. of N.J., 804 F. Supp. 637, 643 (D.N.J. 1992)).

${ }^{72}$ See id. at 1096; see also Payton v. N.J. Tpk. Auth., 691 A.2d 321, 327 (N.J. 1997) (holding that corporations can avoid liability for failure to take remedial measures upon learning of alleged harassment by, for example, undertaking a vigorous inquiry).

${ }^{73}$ See supra Part II.A.3.

74 The law firm Debevoise \& Plimpton conducted the internal investigation concerning whether senior management at Merck failed to disclose the risks of Vioxx. Berenson, supra note 10 . The investigation extended over 20 months, consumed 53,000 hours, and cost $\$ 21$ million. Id. The report consisted of 180 pages, with twenty appendices of another 1500 pages, and was based on interviews with more than 150 witnesses. Id.

${ }^{75}$ Thus, even if the investigation is conducted as a counseling investigation with hopes of preserving the attorney-client privilege and attorney work product, see supra 
problems that can be resolved earlier and increase the prospects that the cancer of wrongful behavior can be excised before it metastasizes to a corporate division or beyond. A well-managed company that receives a credible allegation of material wrongdoing thus has ample reason not only to inquire but to insist that the inquiry satisfy the truth standards that Part III will develop.

\section{INVESTIGATIONS AND THE TRUTH}

Now that we have established what types of investigations pose special concerns about truth or reliability-the reliance and duty investigations-our next task is to determine what standards must be satisfied in such investigations. Although this question is rarely asked, it lies at the core of the investigative role. Commentators and officials tend to emphasize independence in their discussions of investigation reliability. ${ }^{76}$ As we shall see, however, an investigation can be independent but indifferent to other critical reliability concerns.

So what does make an investigation satisfactory? To answer, we must examine the nature and purpose of the reliance or duty investigation to identify its core truth commitment. Thereafter, we will look to insights from law, philosophy, and jurisprudence to refine our understanding of this truth commitment and what it entails. From this, we will develop an account of the core truth or reliability standards or elements that counsel must satisfy in reliance and duty investigations ( "truth standards"). We will also ask how each of these duties should be understood against the background of a client relationship. We will close Part III by identifying and considering four additional implications of the truth standards: the degree of certainty implied by the investigative effort, whether such standards can be disclaimed by investigative counsel in the resulting report, why a detailed analysis

note 18 , the corporation may later decide to waive such privilege and work-product protections and disclose the report to a third party. While the corporation chooses whether to waive attorney-client privilege in the reliance investigation, the corporation may be forced to disclose information developed in certain duty investigations, such as employment-related investigations. See Payton, 691 A.2d at 334 ("If the purpose [of the internal investigation] was to provide legal advice or to prepare for litigation, then the privilege applies. However, if the purpose was simply to enforce defendant's anti-harassment policy or to comply with its legal duty to investigate and to remedy the allegations, then the privilege does not apply."). For a discussion of attorney-client confidentiality under the attorney-ethics rules in light of SarbanesOxley, see Thomas G. Bost, Corporate Lawyers After the Big Quake: The Conceptual Fault Line in the Professional Duty of Confidentiality, 19 GEO. J. LEGAL ETHICS 1089 (2006).

${ }^{76}$ See, e.g., Shepard \& Buehler, supra note 12, at 386; Glassman, supra note 66 ("I would suggest that the company consider conducting an independent internal investigation-and I stress the term 'independent,' in definition as well as spirit.”) 
should accompany conclusions, and how the truth standards help us understand and refine tort duties.

\section{A. An Accurate Account}

An investigator who conducts a reliance or duty investigation is required to develop an accurate account. This issue is best examined from two perspectives. The first asks what the investigator implies in her account of the facts, the law, and their application. The second looks to the intended use of the investigation.

The term "investigation" makes clear that the information presented by the investigator is the result of inquiry and that it is neither conjecture, personal opinion, nor a simple transmission of client information. $^{77}$ It is conducted outside the adversary setting, and thus it cannot take refuge in the adversary theory that truth will emerge from the clash of viewpoints. ${ }^{78}$ The investigation is not the place for advocacy. ${ }^{79}$

If the investigative report is not opinion, conjecture, client information relayed, or advocacy, how can we characterize the information it reports? The internal investigation purports to be based on the knowledge of the investigator. Knowledge, in turn, is generally understood to mean justified and true belief. ${ }^{80}$ Thus, the investigator vouches for the information she offers. Later, this Article will explore the nature of the justification that grounds her propositions ${ }^{81}$ as well as the degree of confidence in the information she presents. Here, the emphasis is on the substantive claim of the internal investigation:

77 See 8 OXFord English Dictionary 47 (2d ed. 1989) (defining “investigation" to include "the making of a search or inquiry; systematic examination; careful and minute research"). For a discussion of the role of disclaimers by investigative counsel about the nature of the investigative inquiry, see infra Part III.D.

${ }^{78}$ For an excellent reconstruction and critique of the truth finding and other rationales that ground the adversary system, see DAVID LUBAN, LAWYERS AND JUSTICE: AN ETHICAL STUDY 67-103 (1988).

${ }^{79}$ See Restatement (ThiRd) OF THE LAW GOVERNing LAWYERS $\$ 95 \mathrm{cmt}$ c c (2000) ("A lawyer providing an evaluation purporting to be a fair and objective evaluation does not function as an advocate for the legal or factual position of the lawyer's client.").

${ }^{80}$ See generally Stanford Encyclopedia of Philosophy, The Analysis of Knowledge (Fall 2008 ed.), http://plato.stanford.edu/archives/fall2008/entries/knowledgeanalysis/ (last visited Oct. 31, 2009) (offering a thorough introduction to the subject, and discussing the famous Gettier problem, which questions the sufficiency of this account of knowledge and the deep disagreement about the nature of justification). The difficulties that philosophers have identified with this definition of knowledge are unimportant for present purposes.

${ }^{81}$ See infra Parts III.A.3, III.B. 
it offers information not as averment, opinion, or guess, but instead as the truth or as an "accurate account."

The recipient is, of course, very much aware of the investigator's commitment to accuracy. Consider the reliance investigation, such as counsel's investigation of a client to be delivered to a third party for the latter's use. ${ }^{83}$ The third party has reason to rely on the investigation and report because the report purports to offer an accurate account. $^{84}$ In addition, the client will also be affected by a report delivered to a third party that describes and analyzes the client's behavior. An investigative report that unfairly implicates the client can harm the client who commissioned the report. ${ }^{85}$ Conversely, a report that unfairly exonerates the client can disserve the third party that relies on the report. An accurate account navigates the only safe harbor between the interests of the client and third party. ${ }^{86}$

A commitment to an accurate account is likewise an essential condition of a duty investigation. Recall that the corporation commissions a duty investigation to fulfill its duty of inquiry under the duty of care or a statutory requirement, such as Sarbanes-Oxley. ${ }^{87}$ If a corporation is to have the benefit of an internal investigation to assist in satisfying its duty of inquiry, it must have reason to believe that the investigation is accurate. Both the duty of care and Sarbanes-Oxley

82 See Am. Coll. of Trial Lawyers, Recommended Practices for Companies And THEIR COUNSEL IN CONDUCTING INTERNAL INVESTIGATIONS, in 1737 PLI/CORP. 459, 478 (Practicing Law Inst., Course Handbook Series PLI Order No. 18499, 2009) [hereinafter ReCOMmended PRACTICES] ("Special Counsel should be instructed to engage in investigative tactics designed to get at the truth, including using their investigative, technological, and professional capabilities."). Although at times this Article will use the terms "truth" and "accuracy" interchangeably, the substantive commitment of the investigation will be termed "accuracy" or an "accurate account" since legal analysis, as we shall argue, may be best understood as the interpretation of the professional community rather than distinct from any person's view. See infra Part III.A.2. As a result, "accuracy" may capture the outcome of the investigator's legal analysis, which in a sense predicts how the legal system will characterize the behavior more precisely than the term "truth."

83 See Model rules of Prof'l Conduct R. 2.3(a) (2007) (allowing lawyer to conduct evaluation "for the use of someone other than the client"); supra Part II.A.3.a.

${ }^{84}$ See Restatement (ThiRd) OF THE LaW Governing LaWyers $\$ 95 \mathrm{cmt}$. c (2000) ("Unless otherwise required or permitted by the terms under which the evaluation is given, the lawyer's duty is to provide a fair and objective opinion.").

${ }^{85}$ It would, moreover, violate MODEL RULES OF PROF'L CONDUCT R. 2.1, which requires candor and independent professional judgment in advising a client.

${ }^{86}$ See Model Rules of Prof'l Conduct R. 2.3(a) (requiring compatibility between client and third-party obligations in order to undertake a reliance investigation).

${ }^{87}$ See supra Part II.A.3.b. 
require reasonable inquiry. ${ }^{88}$ If a corporation does not have reason to believe that the investigative report is committed to developing an accurate account, then that corporation cannot reasonably rely on the investigation in fulfillment of an inquiry duty. ${ }^{89}$

Therefore, an accurate account-as we shall come to define itis the first standard imposed on a reliance- or duty-based internal corporate investigation. The immediate question that such a standard poses, however, is what "accuracy" means and what it entails for the investigator. ${ }^{90}$ If commentators have resisted imposing an obligation of accuracy on an investigator, their concern may stem from the seemingly quixotic nature of such a standard. Does the law really admit of accuracy in an objective sense? If not, how can we require as much from investigative counsel? If so, can we devise a workable standard of accuracy that accommodates the interpretive range of legal questions?

The nature of objective truth presents foundational questions in a variety of settings where inquiry is the norm, ${ }^{91}$ and the problems are no less vexing in the internal-investigation context. If lawyers have averted such controversies in practice, they have done so because their typical calling is advocacy, not objectivity. The question, however, is what must a lawyer do when he seeks not to advocate but to provide an accurate factual and legal account? We turn to this problem next.

\section{Objectivity and Professional Judgment}

A first question is what - if anything - is there for an investigator to be accurate about? This question concerns what philosophers have termed "metaphysical objectivity," whether the "existence and character" of the entity in question is independent of the human mind, including the perceptions, beliefs, judgments of the observer, or, in our case, the investigator. ${ }^{92}$ If the information investigated and reported in an internal investigation is not objective in some metaphysical sense, then the investigative report would be nothing more

${ }^{88}$ See supra notes 63-64 and accompanying text.

89 See Recommended Practices, supra note 82, at 491 (citing goal of independent committee charged with overseeing investigation as, inter alia, "to determine the truth of the underlying allegations").

${ }^{90}$ See infra note 76 and accompanying text.

${ }^{91}$ For an example outside the legal setting, see infra note 98 and accompanying text.

92 See Brian Leiter, Law and Objectivity, in ThE OXFord HandBoOK OF Jurisprudence AND Philosophy of Law 969, 970-71 (Jules Coleman \& Scott Shapiro eds., 2002). 
than an opinion or personal belief of the investigator, and there would be no basis for imposing special truth standards in the investigation.

Three "entities" can be identified in an internal investigation: (1) the facts concerning the allegations of wrongdoing that triggered the investigation; (2) the legal standards that are implicated by the facts; and (3) application of those facts to legal principles to determine whether the alleged wrongdoing has occurred. ${ }^{93}$ Thus, the first question is whether and to what extent the existence and nature of each of the investigation entities (i) depends on what the investigator believes about them, which would qualify as "subjectivism," or (ii) is distinct from what the investigator or anyone else believes, which has been termed "strong objectivism.","

Although categories (i) and (ii) nicely correspond with our initial understanding of objectivity, they are better understood as the boundary categories in a more nuanced account. Philosophers have developed two intermediate categories of how objectivity might be understood given that neither boundary category captures our thinking about certain subjects-fashion or morality, for example. ${ }^{95}$ Thus, "minimal objectivism" holds that what is right is defined by what the community thinks is right, a category that seems to capture our intuitions about how to speak about what is fashionable. ${ }^{96}$ The remaining intermediate category, "modest objectivity," holds that what is right is what "seems right under appropriate or ideal conditions.",

The investigator's search for the facts appears to be the best candidate for the strongly objective account. Our initial sense of what it means to "get it right" with respect to matters such as witness statements, chronologies of events, and material statements reflects the notion that there is truth "out there" that the investigator needs to capture, transcribe, or relay. The ideal of truth-finding has long been controversial among historians, however, whose role in many

${ }^{93}$ Of course, the categories overlap. See George C. Christie, Judicial Review of Findings of Fact, 87 Nw. U. L. REV. 14, 14 (1992) (noting difficulty of distinguishing "questions of fact, questions of law, and mixed questions of law and fact").

94 See Leiter, supra note 92, at 971-93.

${ }_{95} I d$.

${ }_{96} I d$.

${ }^{97}$ See id. Thus, the four categories, ascending toward the ideal of objectivity, are subjectivism, minimal objectivism, modest objectivism, and strong objectivism. 
ways parallels the fact-finding task of the internal investigator compounded further by the ravages of time.

While skeptics have questioned the accuracy with which the legal system describes factual truth, ${ }^{99}$ the critique has hardly persuaded courts to abandon the ideal of truth seeking in the factual setting. Our justice system presupposes that there are objective factual truths. For example, testimony can be true or false ${ }^{100}$ and juries can succeed or err in their search for the truth. ${ }^{101}$ Thus, while the practicalities of truth finding pose fundamental concerns, there is a viable sense in which the first of the investigative entities, the facts, is-for our purposes at least-rightly described as objective in the strongest sense. The truth or falsity of the facts in an internal investigation does not depend on the state of mind of the investigator, the community, or even the conditions under which they are determined. ${ }^{102}$

The next investigative element is the determination of the legal standards and principles that bear on the facts reported by the investigator. Perhaps the most trenchant and influential challenge to the claim of objectivity of law was leveled by the American legal realists; realists generally agree that the multiplicity of precedents, often conflicting, means that few legal standards are mandated in any case, and

98 Compare Edward Hallett CARR, What Is History? 6 (MacMillan, 1961) ("The belief in a hard core of historical facts existing objectively and independently of the interpretation of the historian is a preposterous fallacy, but one which it is very hard to eradicate."), and Barbara W. Tuchman, When Does History Happen?, in Practicing HistoRy 25, 26 (Tuchman et al. eds., 1981) ("I therefore declare myself a firm believer in the 'preposterous fallacy' of historical facts existing independently of the historian . . . [Carr] might just as well say the Grecian Urn would not exist without Keats.”), with Martha Howell \& Walter Prevenier, From Reliable Sources 149 (2001) (acknowledging that many historians today would argue that any "reality that lay behind the sources" is inaccessible no matter how skilled the historian, but that "sources are all we have" and that we can still "learn something by reading them carefully").

99 See Jerome N. Frank, Courts on Trial: Myth and Reality in American Justice 22-23, 37 (3d prtg. 1973). For example, leading American Realist Judge Jerome Frank argued that factual findings are subjective. Id. The reactions of judges and juries are "shot through with subjectivity." Id. H.L. Ho persuasively argues, however, that Frank's statement was not a contention that the justice system is inherently flawed as a finder of fact but a call to reform the system to more closely approach the ideal of objectivity. H.L. Ho, A PHILOSOPHY OF Evidence LAW 56 (2008).

${ }_{100}$ The perjury laws, for example, presuppose as much. See, e.g., 18 U.S.C. $\$ 1621$ (2006); 28 U.S.C. $\$ 1746$ (2006).

101 See FED. R. CIV. P. 52(a) (6) (stating that an appellate court can reverse factual findings below that are clearly erroneous).

102 See Susan Haack, Truths, Truths, "Truth," and "Truths" in the Law, 26 HaRV. J.L. \& PuB. POL'y 17, 19 (2003) ("[F] actual claims at issue in legal proceedings are usually straightforwardly true or else false, and should cause no special unease about truth or objectivity."). 
judges have considerable discretion in the selection of which precedent to apply. ${ }^{103}$ To this might be added the range of techniques for reading precedent, from broad principles to the most confined factual specifics, which affords the decision maker still more discretion. ${ }^{104}$ More fundamentally, others have argued that legal rules are not "complete" because they do not self-identify the situations to which they are applicable. ${ }^{105}$ To this we might add the indeterminate nature of legal standards, as well as the ambiguity of legal language. ${ }^{106}$ Moreover, the application of legal principles may be even more judgment-laden. For example, criminal and civil standards typically require determination of mental states-intentionality, recklessness, reasonableness, and so on. ${ }^{107}$ Certainly, reasonable persons can disagree on what results follow when one applies these and other legal standards to a given set of facts.

Critical legal studies also make claims about the indeterminacy of law. ${ }^{108}$ Regardless of one's position on the more sweeping claims of critical legal studies, many accept the precept that "judgesconservative or liberal-do not find the answers to hard questions in legal precedent or legal logic alone.” ${ }^{109}$ Because judges can interpret statutes and laws in a variety of ways, they "can often find ways to ad-

103 See Wilfrid E. Rumble, JR., American Legal Realism 55-56 (1968).

104 See Karl N. Llewellyn, The Bramble Bush 72-73 (7th prtg. 1981) ("This rule holds only of redheaded Walpoles in pale magenta Buick cars.").

${ }^{105}$ See, e.g., George C. Christie, Objectivity in the Law, 78 YALE L.J. 1311, 1313-14 (1969).

${ }^{106}$ Larry Solum argues that the categories of determinate or indeterminate may not be exhaustive and that law might also be underdeterminate, i.e., there exists more than one choice but not any choice would be legitimate under the applicable rule. Lawrence B. Solum, Indeterminacy, in A Companion to PhilosopHy OF LAW AND LEGAL Theory 488, 489-90 (Dennis Patterson ed., 1996). For an earlier, more extensive treatment of the question (albeit one on which certain of the author's views have since changed), see Lawrence B. Solum, On the Indeterminacy Crisis: Critiquing Critical Dogma, 54 U. CHI. L. REv. 462 (1987). Kent Greenawalt suggests that in many, but not all, cases law is sufficiently determinate to count as objective when all sources and the best arguments are brought to bear on the decision. KENT GREENAWALT, LAW AND ОвјестіVITY 226, 234 (1992).

${ }^{107}$ See Bennett et al., supra note 12, at 59 (arguing that gauging the intent of actors is the "key element" of an internal investigation).

108 See Allan C. Hutchinson, Introduction to CRITICAL LegAL STUdies 1, 4-5 (Allan C. Hutchinson ed., 1989).

${ }^{109}$ Lani Guinier, Foreword to Demosprudence Through Dissent, 122 HARV. L. REv. 4, 121 (2008). 
vance their ideologies through legal argument and still sincerely claim to be upholding the rule of law."

Brian Leiter presupposes that a condition of law's objectivity is its determinacy, i.e., if law is objective, there must be some sense in which there exist "objectively correct answers" to legal questions. By this standard, the critique of the realists and others poses a real challenge, given their arguments that law is anything but determinate. If the investigator can choose from a variety of precedents and exercise considerable discretion in interpreting these standards and applying them to the facts, can we really hope to hold the investigator to a standard of objectivity on questions of law and its applicationthe latter two of the investigative elements?

Law may be best understood as objective in the minimal sense, i.e., what seems right to the community is the right answer. While the opinion of the community may not be right in some ultimate sense, it is objective in that it is in that it both has boundaries and is not based on the state of mind of the judge. " "Conventionalists," for example, argue that:

The judge's choice is constrained by a set of rules (or norms, standards, principles, guides, etc.) that are authorized by the professional community of which the judge is part (and that define and constitute the community) .... Adherence to the rules authorized by the professional community imparts a measure of impersonality to a legal judgment (its objective quality) and at the same time provides the standards for evaluating the correctness of the judgment as a legal judgment." 113

The latter account may come closest to capturing the sense in which an internal investigation can be understood as "accurate." While we cannot measure the investigator's conclusion against some Platonic ideal, the investigator's legal analysis and conclusions-like

${ }^{110}$ Jack M. Balkin, Bush v. Gore and the Boundaries Between Law and Politics, 110 YALE L.J. 1407, 1442 (2001).

111 Brian Leiter, Objectivity and the Problems of Jurisprudence, 72 TEX. L. REV. 187, 197 (1993) (reviewing GreENAWALT, supra note 106).

${ }^{112}$ Id. at 207-08 (reasoning that if law is to constrain us, it cannot be objective in the strongest or modest sense because on such account the correct answers are not accessible to those whom it commands).

${ }^{113}$ Owen M. Fiss, Conventionalism, 58 S. CAL. L. REv. 177, 183 (1985). For an overview of this approach, see Dennis M. Patterson, An Introduction to Conventionalism, 10 W. New Eng. L. Rev. 43 (1988). Dennis Patterson challenges the subjective/objective dichotomy and would direct our search for objectivity away from some "mindindependent" truth and toward a more normative examination of precisely what is agreed upon as being fact. Dennis Patterson, Normativity and Objectivity in Law, 43 WM. \& MARY L. REV. 325, 327-28 (2001). 
those of a judge-are constrained by professional standards of analysis and interpretation. ${ }^{114}$

The idea that the standards of the professional community serve as boundaries for legal interpretation is consistent with the degree of judgment that undeniably is at work in rendering a legal assessment. As Brad Wendell has observed, rules alone do not mandate conclusions to legal questions:

The decision maker must consider texts, principles, and facts, as well as subsidiary norms such as rules of legal salience (which point to aspects of the facts that are germane to the decision), considerations of weight and priority among competing norms, and the possibility of justified departures from previously sanctioned interpretations.

This interpretive element explains how judges can arrive at differing interpretations in the same matter without undermining the claim that law is, in some sense, objective. ${ }^{116}$ A decision is no longer objective when it strays beyond the boundaries of acceptable professional interpretation of the materials. ${ }^{117}$ This appeal to professional standards as the source of law's objectivity has particular resonance for the inquiry here. The investigator's report is valued not for its idiosyncratic "take" on the law and its application but for its prediction of how the legal system would assess the behavior in question. ${ }^{11}$

Thus, the "right answer" in an internal investigation may exist in only the weakest metaphysical sense for certain aspects of the investigation, such as law or its application. Nonetheless, the existence of a right answer-even if based on only the accepted interpretive standards of the legal community-implies that investigative analysis is independent of the mind of the investigator who seeks it. The investigator has, in other words, a substantive goal—an accurate account

114 See W. Bradley Wendel, Professionalism as Interpretation, 99 Nw. U. L. REV. 1167, 1191 (2005) (arguing that legal judgment "is a community-bound enterprise, in which the criteria for reasonable exercise of judgment are elaborated intersubjectively, among an interpretive community that is constituted by fidelity to law").

${ }^{115} I d$. at $1193-94$

116 Id. at 1195 ("An observer might disagree with $\mathrm{B}$, and believe that A was the better result, but nevertheless concede that $\mathrm{B}$ was within the range of plausible, justifiable results.").

${ }^{117}$ Owen M. Fiss, Objectivity and Interpretation, 34 STAN. L. REV. 739, 748 (1982).

118 Of course, conventionalism is not the only means by which we might seek to arrive at an objective account. For example, Ronald Dworkin famously argued that there is a right answer to legal questions, albeit in some instances discernable only by the interpretive efforts of a superhuman Judge Hercules, in selecting the principle that coheres best with the "great network of political structures and decisions" of the community. RONALD DWORKIN, LAW'S EMPIRE 245 (1986). 
of the law, the facts, and their application. Our next concern is what this goal means in practice.

\section{Objectivity and Procedure}

If the facts, law, and their application are objective in some sense, however modest, then there is reason to adopt procedures that will lead us to an "accurate account." This is what philosophers have termed "epistemological" objectivity, i.e., the cognitive and procedural elements that enhance our prospects of arriving at the right answer. "Epistemological objectivity obtains when either of the following is true: (1) the cognitive processes at issue reliably produce accurate representations, or (2) the cognitive processes are free of factors that are known to produce inaccurate representations." ${ }^{120}$

Epistemological objectivity does not demand that we arrive at an exact representation of the facts or law, which may be more than is "attainable." In practice, given the limits of the investigative process, we know that no account can achieve the ideal of perfect accuracy. The investigator's goal, therefore, is to achieve as accurate an account as is practicable. ${ }^{122}$ To this end, we must adopt cognitive processes that reliably lead to accuracy and eliminate those factors known to produce inaccurate accounts.

Thus, the next step is to identify standards that will increase the prospects of developing an accurate account in an internal investigation. The reliability factors must be specific not only to the domain of law but also to the investigative setting. The investigative domain differs starkly from the adversarial approach to truth finding. In the adversarial setting, the clash of interests, factual accounts, and legal arguments assists the jury or judge in reaching a correct understanding of what transpired, what legal standards govern, and what result

119 See Leiter, supra note 92, at 973.

${ }^{120}$ Id. As noted earlier, for the investigator to claim knowledge with respect to an assertion in an investigative report, she must, on the traditional account, have a justified true belief. On some "reliabilist" accounts of knowledge, the reliability of the cognitive process provides this justification or supplants the justification element entirely. Stanford Encyclopedia of Philosophy, supra note 80.

${ }^{121}$ Leiter, supra note 92, at 973.

122 FRANK, supra note 99, at 35-36 (stating with regard to the legal system that "[p]erfect justice lies beyond human reach[, b] ut the unattainability of the ideal is no excuse for shirking the effort to obtain the best available").

${ }^{123}$ The procedures that enhance reliability will vary with the domain in question; for example, law implicates different epistemological-objectivity concerns than science. Leiter, supra note 92, at 973. 
they mandate. ${ }^{124}$ The adversary system, in other words, is a procedural means to enhance accuracy. In the investigative setting, where there is only one voice, we must be sensitive to the absence of this process and rely instead on other tools that tend toward reliability. The truth standards that follow are designed to produce epistemological objectivity in the investigative domain. They are, in other words, procedural means that lead reliably to an accurate account in an internal investigation.

\section{B. The Truth Standards: Tools of Accuracy}

As previously discussed, the investigator must employ procedures that are designed to lead to an accurate account. To this end, we will identify and examine four procedures that are especially valuable in this search and that reflect the special, nonadversarial role of the investigator-independence, sufficient inquiry, evidentiary reliability, and professional judgment. While the standards that follow are not intended to be exhaustive, they are fundamental procedures that substantially increase the prospects of an account that is accurate and, therefore, worthy of reliance.

\section{Independence}

An investigator who has an obligation or an interest that will be disserved by offering an accurate account is less likely to do so. In both reliance and duty investigations, there is deep potential for conflict between an investigator's finding of wrongdoing and the client's interest in avoiding such culpability. In the reliance investigation, a conflict that diverts an investigator from the truth will typically disserve the interests of the third party that relies on the report. In the duty investigation, the same conflict can prevent the client from receiving a report that satisfies the duty to inquire, thereby harming the shareholders or others whom the duty is designed to protect. Thus, the accurate-account standard warrants protection against conflicts of interest that can undermine the reliability of the internal investigation. ${ }^{125}$ We will term this the independence standard. ${ }^{126}$

\footnotetext{
${ }^{124}$ For an analysis of the justifications for the adversary system and a critique of those reasons, see LUBAN, supra note 78, at 67-103; DAVID LUBAN, LEGAL ETHICS AND HUMAN DigNiTY 19-64 (2007).

${ }^{125}$ Although accuracy provides the principal grounding for the prohibition on conflicts, MODEl RUles OF PROF'L COND. R. 2.3(a) (2007) provides additional support for reliance investigations in the requirement that the investigative role must be "compatible with other aspects of the lawyer's relationship with the client." The Sarbanes-Oxley Act provides additional support for duty investigations in $\S 307$, which authorizes the audit committee of the board of directors to retain independent
} 
Two categories of conflict can undermine the accuracy of an internal investigation. The first stems from the investigator's commitments to advance client interests on issues that relate to the investigation, which we will term "advocacy conflicts." The second concerns interests of the investigator that might divert her from the truth, which we will term biasing interests. We will consider each in turn.

The advocacy conflict flows from the divergent demands of the representative and investigative roles. The advocacy role frees counsel from any pretense of objectivity or impartiality and requires counsel to shape her arguments and the presentation of facts to advance the client's view, short of knowing misrepresentation and other ethical and legal limits. ${ }^{127}$ The investigative role demands objectivity. One who seeks to advocate and protect one party is, by definition, not objective with respect to such issue. Thus, an investigator can have no advocacy functions with respect to the conduct and report of the investigation. ${ }^{128}$ As used here, "advocacy" is not limited to the litigation role but denotes any obligation or effort of the investigative attorney to protect or advance the interests of the client related to an issue in the investigation. To cite an obvious example, an attorney charged with minimizing the exposure of the client on an issue has an advocacy conflict that precludes her service in the investigative role with respect to such issues.

The call for neutrality on all issues related to the investigation, though hardly surprising, presents a real practical challenge in the investigation. The client retains investigative counsel, pays for the investigation, is the subject of the investigation, and has a deep, vested interest in the outcome of the investigation, since criminal and civil liability may hinge on the findings. Thus, the gravitational pull of the

counsel. Pub. L. No. 107-204, § 307, 116 Stat. 745, 784 (2002). Although the Act describes the independence required of audit committee members, it does not elaborate on what constitutes an "independent" investigator or establish any other standards with respect to the investigation. See Shepard \& Buehler, supra note 64, at 387.

${ }^{126}$ Although the emphasis here, as elsewhere, is on the truth obligations of investigative counsel, it should be noted that the corporate client has grave potential for conflicts of interest that can undermine the trustworthiness of their conclusions. The allegations might, for example, allege wrongdoing against senior management or the corporation itself. Thus, in these and other instances of conflict, the corporation should delegate the supervision of the investigation to the audit committee of the board of directors or to a committee of independent directors. See RECOMMENDED PRACTICES, supra note 82, at 476.

${ }^{127}$ See Gerald J. Postema, Moral Responsibility in Professional Ethics, 55 N.Y.U. L. Rev. 63, 73 (1980) (analyzing the "standard conception of the lawyer's role"). For a book-length critique of the standard conception of advocacy, see WiLliam H. SimON, The Practice of Justice: A THEORY OF LAWYERS' ETHICS (1998).

128 See Restatement (THIRD) OF THE LAW GOVERning LAWYERS $§ 95 \mathrm{cmt}$. c. 
client is considerable, but investigative counsel must resist it if she is to remain objective. Investigative counsel cannot assume any advocacy roles with respect to the conduct and reporting of an investigation that is subject to the truth standards. ${ }^{129}$ Moreover, advocacy objectives are not strictly those that are overtly adversarial but include less obvious efforts to protect or advance the interests of the client-as we shall see in Part IV, which considers the truth standards in application. Thus, lawyers who would serve as investigators must don the hat of neutrality, no small feat for American lawyers who practice in such a litigious and adversarial legal system. ${ }^{130}$

A second category of interests can steer the investigation away from the truth. These biasing interests include interests of the investigator that threaten to undermine her commitment to an accurate account. Examples of interests that may qualify as biasing include the investigator's longstanding employment by the client, which a negative investigation report may jeopardize; a financial interest in the client; and close personal relationships with the persons under investigation. $^{131}$

The role of biasing interests must be considered more closely, however, before we flatly prohibit them in service of our independence standard. Unlike an advocacy conflict, which disserves either the attorney-client role or a third-party interest (unless the truth happens to help the client's cause), a biasing interest does not guarantee a faulty investigative effort or report. An investigator may simply rise above her interest in preserving a job, client, or friendship and report the unvarnished truth despite the consequences.

If a biasing interest will not necessarily skew the investigation, why and when should we prohibit them? As Andrew Stark explains, biasing interests are especially problematic when the role in question involves discretion and judgment. ${ }^{132}$ As discussed earlier, on the con-

129 See Model Rules of Prof'L CONDuct R. $2.3 \mathrm{cmt} .3$ (2007) (noting that an attorney who serves as an advocate for the corporation with respect to an allegation of fraud has an irreconcilable conflict in providing an evaluation for a third party on that issue). Thus, conflicts of interest pose not only grave concerns about the reliability of the investigation, but ethical concerns for investigative counsel as well.

${ }^{130}$ See Robert A. Kagan, Adversarial Legalism: The American Way of LaW 3 (2001) ("American methods of litigating and adjudicating legal disputes are more costly and adversarial" than in other "economically advanced democracies.").

131 See infra Part IV.A.1 (discussing cases that have considered these various bias interests).

132 Andrew Stark, Conflict of InTERest in American Public Life 22-23 (2000). In the policy-making arena, where Stark directs much of his inquiry, decisions are presumably more judgment-based than in the investigation setting addressed here, where legal conclusions have a stronger (though qualified) claim to objectivity. See 
ventional view, the interpretive standards of the professional community constrain legal assessments, but such standards do not eliminate the judgment and discretion entailed in conducting an internal investigation. ${ }^{133}$ These include decisions over how to characterize the underlying question and the scope of the investigation; whom to interview; what questions to ask; whose statements are trustworthy and whose are not; what facts, statements, and documents deserve emphasis; and the application of law to the factual narrative developed. ${ }^{134}$ Moreover, the allegations that trigger the investigation often require the investigator to assess the mens rea of the participants, since criminal liability often turns on whether the wrongdoing was intentional or otherwise. $^{135}$ Thus, on a question that often lies at the core of the investigation, the investigator may be asked to make fine-grained judgments about the subjective states of actors, ranging between knowing, intentional, reckless, and negligent. While these judgments are bounded by the constraints of professional interpretation, there is sufficient range within such boundaries for an investigator's conclusion to appear legitimate even if biased. ${ }^{136}$

The recipient of an investigative report is therefore left with the difficult question of whether to trust the report. Given the considerable consequences that attach to reliance on the results of an internal investigation, the question is critical. A recipient of the report could examine the contents of the report for clues to the extent and thoroughness of the investigation, the internal consistency of the analysis, the depth and quality of the reasoning, and whether the facts developed and legal standards applied support and are consistent with the conclusions. This sort of inquiry is valid and helpful, but it will more likely discern whether the investigator has crafted a report that is within the canons of professional judgment, not whether it was free from bias. Thus, bias interests create a genuine risk of compromising the truth in an internal investigation, and the recipient of the report

supra Part III.A.2. For an insightful review of Stark's work, see W. Bradley Wendel, The Deep Structure of Conflicts of Interest, 16 GEO. J. LEGAL ETHICS 473 (2003) (book review).

${ }^{133}$ See supra notes 112-18 and accompanying text.

134 See infra Parts III.B.

${ }^{135}$ Bennett et al., supra note 12, at 58-59 ("Understanding why employees acted as they did is . . . the most subtle and important goal of the internal investigation. It amounts to a 'search for intent,' which is the key element in most criminal cases involving corporate misconduct.").

${ }^{136}$ Wendel, supra note 132, at 475 (noting that there are no "algorithms" by which to evaluate the correctness of legal decisions after the fact). 
will have no viable means of determining whether in fact that was the case.

The Model Rules offer guidance in their treatment of a bias in a distinct but analogous setting, barring an attorney from representing a client if there is a "significant risk" that the attorney's personal interests "materially" limit the client representation. ${ }^{137}$ The Restatement of the Law Governing Lawyers adopts a similar approach, prohibiting representation if there is a "substantial risk" that the lawyer's "financial or other personal interests" will "materially and adversely" affect the representation. ${ }^{138}$ The Restatement standard, moreover, is grounded on a rationale that parallels our concern regarding bias interests in the investigation setting: personal interests can undermine the pursuit of client interests, and it is difficult to discern, after the fact, whether counsel has subordinated his personal interests to serving the client. ${ }^{139}$

The standard is helpful in analyzing what biasing interests are unacceptable in the investigation. Counsel should not conduct an internal investigation if there is a substantial risk that the interests, incentives, or obligations of investigative counsel arising out of the relationship with the client would materially divert the investigator from providing an accurate account. In Part IV, we will consider this standard in practice.

Independence alone is not enough to warrant confidence in the reliability of an internal investigation, though commentators and officials sometimes imply that it is sufficient. ${ }^{140}$ The goal of an internal investigation is an accurate account, not independence. ${ }^{141}$ Independence is one of a series of tools designed to enhance reliability. An independent investigation is not reliable if it is hampered by insufficient inquiry, indifference to the reliability of the evidence, or a failure of professional judgment.

${ }^{137}$ Model Rules of Prof'́l Conduct R. 1.7(a) (2) (2007).

${ }^{138} I d$.

139 RESTATEMENT (THIRD) OF THE LAW GOVERNING LAWYERS $§ 125 \mathrm{cmt}$. b.

${ }^{140}$ See supra note 76 and accompanying text.

${ }^{141}$ See Kaplan et al., supra note 12, at 1022 ("Indeed, independence can be viewed not as an end in itself, but as a means of ensuring that issues of corporate misconduct will be addressed in an open-minded, objective manner."). The article proceeds, however, to treat the adequacy of an investigation as evidence of "independence," a conceptual conflation resulting from the failure to identify the core substantive goal of the investigation, accuracy, and to treat the procedural reliability standards as distinctive means to such end. See id. 


\section{Sufficient Inquiry}

We turn next to the scale of the inquiry that must ground an investigative report. If the factual findings of the report are to be accurate, they must be based on an inquiry that is sufficient to uncover the facts concerning the alleged wrongdoing. ${ }^{142}$ Likewise, the research that grounds the legal analysis in an investigative report must be sufficient to determine the legal standards that the factual findings implicate. ${ }^{143}$

As a practical matter, of course, there must be some limits on the extent of the inquiry. With respect to factual findings, the accuracy standard requires investigative counsel to approach as closely as practicable the truth of what happened. One way to conceptualize the practical limits of such an inquiry is to ask whether additional investigation would pose a genuine prospect of discovering information that will have a material effect on the findings. ${ }^{144}$ Phrased affirmatively, the investigator must inquire into the facts of the allegation until additional investigation no longer presents a genuine prospect of gaining information that will materially affect the findings. ${ }^{145}$ This formulation also describes the extent of the investigator's research into the legal standards that are implicated by the factual findings. The investigator must research the legal standards implicated by the factual findings until additional research no longer presents a genuine prospect of gaining information that will materially affect the analysis or conclusions. We will term this description of the factual and legal inquiry that should ground an investigative report the "sufficient-inquiry standard," which is the second of the truth standards designed to enhance the prospects of an accurate account. ${ }^{146}$

142 See Model Rules of Prof'l Conduct R. 2.3 cmt. 4 (2007) ("The quality of an evaluation depends on the freedom and extent of the investigation upon which it is based.").

${ }^{143}$ For cases considering the sufficiency of investigation, see infra note 221.

144 The term "genuine prospect" is chosen to dispel the false sense of precision that would accompany a standard that was quantitatively framed, such as preponderance or likelihood.

${ }^{145}$ The standard here is higher than that of relevant evidence, which means "evidence having any tendency to make the existence of any fact that is of consequence to the determination of the action more probable or less probable than it would be without the evidence." FED. R. EvID. 401. Instead, the concern is whether the investigator's findings would be materially altered by additional information, a standard more closely akin to the various definitions of materiality offered in the securities setting. See, e.g., Basic, Inc. v. Levinson, 485 U.S. 224, 231-32 (1988).

${ }^{146}$ Although the sufficiency standard derives principally from the accurateaccount standard, an array of additional standards also support it. The attorney who delivers an investigative report expressly or impliedly states that the information is 
Like all of the truth standards, the "sufficient-inquiry standard" poses a potential for conflict with client interests. In a standard representation, the client has the authority to define (within limits) the scope of the agreed representation and to place reasonable limits on the expenditures of counsel. ${ }^{147}$ Likewise, in the investigation context, a client understandably may not want the inquiry to extend beyond the reasonable boundaries of the matter at hand and does not want to issue a blank check to investigative counsel. These client concerns, however, can also serve as a pretext for subverting the investigative process. The client may wish to impose limitations on the inquiry simply to reduce cost regardless of the effect on the quality of the investigation. The client may seek to limit counsel's investigation, including investigative counsel's access to certain documents or witnesses, in order to reduce the prospects of uncovering wrongdoing. With respect to these disagreements, investigative counsel should accept no client-imposed limitation on the investigation that will prevent her from complying with the sufficient-inquiry standard.

The investigator has ample leverage in resisting client-imposed limitations that undermine sufficient inquiry, since they are likely to preclude her from producing an account that is worthy of reliance by the client or a third party. ${ }^{148}$ Conversely, the client retains the unfettered right to terminate investigative counsel at any time, ${ }^{149}$ which remains an important client protection against unjustified expenditure or other inappropriate behavior on the part of investigative counsel. In practice, these competing demands require a delicate touch to ensure that neither the truth standards nor the client's interest in reasonable expenditure is compromised. ${ }^{150}$

\section{Evidentiary Reliability}

Investigators gather evidence and develop findings of fact relating to matters that are the subject of the internal investigation. The

backed by her (or her firm's) inquiry. Therefore, an investigative report that is not backed by such inquiry violates MODEL Rules OF Prof'L CONDUCT R. 3.3 and 4.1, which prohibit false statements by counsel to courts and third parties, respectively. Moreover, a duty investigation that does not satisfy the sufficiency standard would not satisfy the reasonable investigation standards of the duty of care and SarbanesOxley. See supra notes 62-63 and 67-69 and accompanying text.

${ }^{147}$ See MODEL Rules R. 1.2(a) (providing that lawyers abide by client decisions regarding objectives of representation); $i d$. cmt. 2 (noting that lawyers defer to clients regarding questions of expense).

${ }_{148}$ See infra Part III.D for a discussion of investigation difficulties and their effect on the investigator's conclusions.

149 Model Rules of Prof'L Conduct R. 1.16(a) (3).

${ }^{150}$ See infra Part IV. 
reliability of the evidence gathered is, of course, essential to the accuracy of the investigator's account. The investigation, however, is conducted outside the adversary process, which can be understood and justified in substantial part as a tool to enhance accuracy. ${ }^{151}$ Thus, our third evaluation standard, evidentiary reliability, requires that the investigator address the special concerns regarding the reliability of evidence that flows from the absence of adversarial or judicial checks on the investigative process. In addition to finding facts, evidentiary reliability calls for care and deliberation in evaluating the evidence collected. ${ }^{152}$

Consider the testimony of the witnesses in a contested matter. If material, that testimony is likely to be challenged rigorously by opposing counsel, who will search for inconsistencies with the witnesses' prior statements, inconsistencies with other witnesses and documents, biases, deficiencies of perception, and problems of credibility. ${ }^{153}$ The investigator, by contrast, risks a certain passivity in this regard; she does not assume a questioning stance as a natural consequence of the self-interest that motivates an opposing party, but she also must not simply presume testimony and other evidence trustworthy due to the absence of contrary evidence. The investigator, if she is to approach the rigor of the adversary process, must search actively for reliability problems from an imagined opposing perspective. ${ }^{154}$

This is not to suggest that an investigator can elicit accurate and reliable testimony only by cross-examining interviewees with the bearing of an incredulous adversary. On the contrary, the witness who is treated fairly and with respect is likely to cooperate and provide a more thorough account. ${ }^{155}$ The investigator's challenge, however, is

151 See supra notes 11, 124, 127 and accompanying text.

152 See Ho, supra note 99, at 46 ("Findings of fact should not issue directly from intuitive gut feelings. Insofar as they are supposed to be deliberated conclusions, the findings must be reached by identifying the reasons for the views tentatively held about the facts, and by reflecting on the validity and strength of those reasons. This process of evaluation may lead to confirmation of the original views, or it may lead to their abandonment or revision.").

153 See generally MCCORMick ON Evidence $§ \S 19-48$ (Edward W. Clearly ed., 3d ed. 1984) (discussing cross-examination and impeachment of witness); MichaEL E. TigAR, EXAMINING WiTNESSES 187-249 (2d ed. 2003) (discussing cross-examination).

${ }^{154}$ Investigative counsel must take care to explain that she represents the corporation or audit committee and not the witness, who may be an employee and therefore confused about the investigator's loyalty. MODEL Rules OF PROF'L CONDUCT R. 1.13(f). See also Recommended Practices, supra note 82, at 485-89 (discussing an array of other steps that investigative counsel should take to avoid treating witnesses unfairly).

${ }^{155}$ See Randall J. Turk \& Mark Miller, The Witness Interview Process, in INTERNAL CORPORATE INVESTIGATIONS, supra note 12, at 93, 108. 
to elicit and challenge the testimony of a witness concurrently. The absence of adversity offers not only a risk but an opportunity in this regard. Because the matter is not contested, the investigator has no incentive to engage in histrionics, exaggeration of minor discrepancies, embarrassment of witnesses, or other excesses to move a jury.

The investigator not only combines the role of direct examiner and (respectful) cross examiner, she is also the judge and jury. At trial, the judge makes threshold determinations about authenticity of documents as well as the admission of evidence. ${ }^{156}$ These questions are no less important in the investigative role, but as judge and fact finder the investigator will be exposed to evidence that may be inadmissible at trial because it is untrustworthy-for example, prejudicial statements ${ }^{157}$ or hearsay that is not otherwise admissible. ${ }^{158}$ Thus, the investigator must not only question the trustworthiness of the evidence she uncovers, but must also not allow the unreliable evidence to which she is exposed to affect her findings of fact. ${ }^{159}$

In addition, as historians have long acknowledged, selection and emphasis can profoundly shape the factual narrative, even if it is grounded on reliable sources. ${ }^{160}$ This concern cannot be swept away by an injunction against bias. Like the other evidentiary-reliability concerns, however, the bias of selection and emphasis can be tempered by the investigator's awareness of the problem and efforts to minimize the distorting effects. ${ }^{161}$ Even if no account corresponds perfectly with reality, an account that is sensitive to the dangers posed by selection and emphasis will come closer than one that is not.

${ }^{156}$ FED. R. EvID. 104(a)

157 See FED. R. EVID. 403

158 See FED. R. EvID. art. VIII.

159 This is not to suggest, however, that the investigator must comply strictly with the Rules of Evidence in developing a factual account. The Rules do, however, identify types of evidence that can undermine the truth finding function, such as hearsay, unauthenticated documents, prejudicial statements, and so on. A sensitivity to these and other concerns identified by the Rules will reduce the risk of an inaccurate account.

${ }^{160}$ See Tuchman, supra note 98, at 49 ("The problem is how and what to select out of all that happened without, by the very process of selection, giving an overemphasis or under-emphasis which violates truth. ... The job is to achieve a narrative line without straying from the essential facts or leaving out any essential facts and without twisting the material to suit one's convenience.”).

${ }^{161}$ See Howell \& Prevenier, supra note 98, at 148 ("The trick, then, is to construct our interpretations responsibly, with care, and with a high degree of selfconsciousness about our disabilities and the disabilities of our sources."). 


\section{Professional Judgment}

As we have seen, the investigator's obligation to deliver an accurate account raises difficult questions about what it means to be accurate in a legal matter. ${ }^{162}$ Laws, legal standards, and their application to a particular set of facts often require interpretation. Given this interpretive element, it is tempting to assume that the investigator's task is to offer her own "take" on the issues. The notion could hardly be more mistaken. As discussed earlier, while law requires interpretation, that interpretation is hardly unbounded. Law's objectivity is grounded in the interpretive standards of the legal community. ${ }^{163}$

Thus, our fourth truth standard is professional judgment. The investigator must employ accepted professional standards of legal interpretation and reasoning to analyze and apply the law, and to reach legal conclusions. These professional norms guide and constrain the investigator. The investigator's legal conclusions are valuable to the extent that they accurately describe how the legal system would characterize the behavior in question. The investigator can arrive at "accurate" legal conclusions only through application of the interpretive standards and norms of the legal community, and not by giving voice to her personal predilections. ${ }^{164}$

The canons, norms, methods, and standards that comprise professional judgment are instilled through legal education, training, and practice, and thus do not bear useful summary here. ${ }^{165}$ We will limit ourselves here to a few comments to dispel basic misconceptions. While its goal is to enhance an objective or accurate account, professional judgment does not require a rigid or literal-minded approach to legal interpretation when "a myopic fixation on the literal language of the statute would cause an interpreter to miss the apparent meaning of the text." " Conversely, professional judgment does not allow the interpreter "to impose her own policy preferences on the text."167 The path between these markers is, of course, the essence of professional judgment. It may be the highest calling of the investigator.

${ }^{162}$ See supra Part II.A.2.

163 See supra notes 111-18 and accompanying text.

${ }^{164}$ By analogy, as Owen Fiss argues, "Judges know that if they relinquish their membership in the interpretive community, or deny its authority, they lose their right to speak with the authority of the law." Fiss, supra note 117 , at 747.

${ }^{165}$ For an excellent theoretical and practical treatment of professional judgment, see Wendel, supra note 114, at 1167.

${ }^{166} I d$. at 1187.

${ }^{167} I d$. 
Professional judgment should also inform the investigator's interpretation and application of the other truth standards. For example, although the sufficient-inquiry standard offers a method for determining when further inquiry is necessary, it, like most standards, is not self-applying. The investigator is required to exercise professional judgment in determining, inter alia, whether to engage in additional inquiry. The investigator's interpretation of the truth standards, like any principles designed to offer general guidance, must be guided by the standards' objective of enhancing the reliability of the investigator's account. Reliability remains the touchstone of the investigator's efforts, and her sound professional judgment must inform interpretation and application of the standards designed to foster that goal.

\section{The Degree of Certainty}

The investigator expressly or impliedly claims that her findings of fact and conclusions of law are reliable or accurate because they are grounded in sound epistemological procedures and because they are guided and disciplined by sound professional judgment. ${ }^{168}$ Neither of these methods, however, claims to be foolproof. The truth standards, even when satisfied, do not guarantee accuracy in findings of fact. Moreover, legal interpretation, even when constrained by professional standards, will produce varied outcomes that can all fairly be termed legitimate. ${ }^{169}$ Thus, the investigative report does not claim to offer certainty with respect to its findings and conclusions.

To what degree of confidence does an investigator present her findings of fact and law? In many ways, the standard adopted by some jurisdictions for admission of expert testimony-a reasonable degree of professional certainty or probability ${ }^{170}$ - offers a useful guide here. The investigator's conclusions are reasonably reliable because she has adhered to reliable procedures and engaged in the professional interpretation of the law. The conclusions are not certain, however, because neither the procedures nor legal interpretation admit of certainty. The standard rejects the poles of certainty and conjecture, ${ }^{171}$ and looks instead for reasonable certainty or reliability. The recipient of an investigative report has the right to presume as much about the investigator's conclusions.

${ }_{168}$ See supra Parts III.A and B.

169 See supra note 116 and accompanying text.

170 See, e.g., McMahon v. Young, 276 A.2d 534, 535 (Pa. 1971) (citing Mendarde v. Philadelphia Transp. Co, 103 A.2d 681 (1954)).

${ }^{171}$ See Johnston v. Indus. Comm'n, 87 N.W.2d 822, 825 (Wis. 1958). 
Part III.D-E will consider two additional implications of the investigator's commitment to an accurate account. Given that the truth standards ground the investigator's conclusions, we will consider next the significance of the investigator's failure to satisfy these standards. Thereafter, we will explore the question posed by the role of professional judgment in the investigation: if professionals can disagree on matters of interpretation, why should an investigator's conclusions be trusted?

\section{Reliability Qualifications}

When the investigator cannot satisfy one or more truth standards, we have reason for concern about the reliability of her findings of fact and conclusions of law. At first blush, "limitations" or "qualifications" that identify problems with the investigation seem to offer an obvious solution. On this view, the investigator presents findings of fact and conclusions of law to the reader and candor then requires disclosure of any material conditions that lessen their reliability. On closer inspection, however, problems affecting the reliability of the investigation may or may not lend themselves to simple resolution with a list of qualifications of the findings of law and fact.

When the investigator offers both conclusions and qualifications, the reader of the report must evaluate the significance of limitations on the investigation or its analysis. If an investigator is required to develop the facts and analyze and report on their significance, why should we assume that the reader is an expert at measuring their reliability? Consider what is left unanswered by this approach. Is the investigator asserting that the findings of fact and legal conclusions are accurate despite the qualifications? Or is the investigator suggesting that the conclusions are not to be trusted because of the qualifications? If the former, how is it possible that material limitations affected the investigation but the outcome remains trustworthy? If the latter, why has the investigator presented facts and conclusions when the limitations precluded development of a trustworthy account? More generally, if the investigator has sufficient discretion to determine which limitations on the investigation were material and thus necessary to qualify the report, why is she unable to discern their effect on the report itself?

In fact, the professional judgment entailed in developing findings of fact and conclusions of law is inexorably tied to an assessment of the quality and extent of the information uncovered in the investigation. An investigator cannot "find" a fact unless she has adequate 
reason to believe that fact so. ${ }^{172}$ If, for example, a critical part of factfinding is an assessment of the credibility of the witnesses and their relation to other witness statements and documentary evidence, ${ }^{173}$ an investigator cannot be agnostic about whether she has access to such information. Thus, an investigator's assertion about the facts and their legal significance implies a great deal about the provenance of both assertions. If an investigation is hampered by a material limitation, one has a right to question not only the reliability of the investigator's conclusion but why she has offered a conclusion at all.

Let us begin to unravel the mystery by identifying with some precision the problems with the investigation that must be disclosed by an investigator. A material qualification warranting disclosure is any aspect of the investigation, analysis, or reporting that does not satisfy the truth standards or otherwise poses a genuine prospect of undermining the reliability of the investigation. ${ }^{174}$ Clearly, the investigator must disclose such qualifications under legal ethics principles ${ }^{175}$ and tort standards ${ }^{176}$ to avoid deceiving the reader.

The investigator must do more than simply identify material qualifications, however. Conclusions and qualifications in tandem suggest that the conclusions of fact and law are "reliable" in the investigator's professional judgment, but that the investigation that gave rise to these conclusions might pose material questions about reliability. The reader cannot be expected to solve this riddle. The investigator, and not the report recipient, has direct access to witnesses and the opportunity to evaluate their credibility based on their demeanor and their reaction to challenges and contrary evidence; ${ }^{177}$ the advan-

${ }^{172}$ See supra note 80 and accompanying text.

173 See supra Part III.A.3.

${ }^{174}$ Again, the truth standards do not purport to be exhaustive, and thus there may be other failings that threaten the reliability of the investigation that warrant disclosure.

${ }^{175}$ See Model Rules of Prof'L Conduct R. $2.3 \mathrm{cmt} .4$ (2007) (providing that limitations on investigation should be noted in report); $i d$. R. 4.1 (prohibiting knowing misstatements by counsel to a third party); id. R. 3.3(a)(1) (prohibiting knowing misstatements to court); $i d$. R. 2.1 (requiring candor and independent professional judgment in advising the client).

1761 Geoffrey C. Hazard, JR. \& W. William Hodes, The LaW OF LaWyering $\$ 25.4$ (3d ed. Supp. 2010) ("A lawyer would almost certainly be liable in tort (for fraud or misrepresentation) if material limitations were not disclosed when third parties justifiably assumed that there were none.").

177 See, e.g., State v. Locurto, 724 A.2d 234, 238 (N.J. 1999) (requiring deference to fact finder on questions of credibility). For a general discussion of evidentiary reliability, see supra Part III.B.3. 
tage of selection and emphasis in the reporting of facts; ${ }^{178}$ deeper, first-hand insight into the need for additional investigation and the risks to accuracy posed by the unavailability of witnesses; ${ }^{179}$ and the obligation to exercise professional judgment in assessing the mens rea of the actors in question and applying the facts to legal principles. $^{180}$ Even assuming the reader has the time, resources, and disposition to examine each of these issues, the questions are inherently contextual; they presuppose an understanding of the circumstances and settings in which the investigator's decisions were made. It is difficult to imagine what information-shy of conducting the investigation anew-could supply the report recipient with such context.

Thus, while the recipient must remain vigilant about the accuracy of the investigation and report, the investigator has insight into the reliability of an investigation that the recipient of the report cannot hope to replicate. ${ }^{181}$ The investigator, by contrast, has better information and also insight into how investigative deficiencies affected the outcome. An investigator who does not know whether or how limitations on the investigation affected the reliability of her conclusions has not engaged in sufficient deliberation about the truth standards to deliver a report. ${ }^{182}$

A failure to satisfy one or more truth standards, or some other material deficiency in the investigation, can potentially affect the outcome in three ways. First, and most likely, the failure to satisfy the truth standards will render a conclusion inappropriate for one or more factual or legal questions. If the truth standards substantially enhance the prospect of an accurate outcome, their absence substantially increases the prospect of inaccuracy. Thus understood, counsel has overwhelming incentive to comply with the truth standards, since their absence will likely foreclose her from offering a factual finding or legal conclusion on the issues affected by the deficiency. By extension, the client has incentive not to prevent counsel from satisfying the truth standards because, by commissioning an investigation, the client presumably wishes counsel to produce a report that offers findings and conclusions on the issues. ${ }^{183}$

Second, and perhaps least likely, the investigator may conclude that the failure to satisfy the truth standards did not prevent her from

${ }^{178}$ See supra Part III.B.3.

179 See supra Part III.B.2.

180 See supra Part III.B.4.

181 See infra Part III.E.

182 See supra note 152 and accompanying text.

183 See supra Part II.B. 
reaching a reliable conclusion on an issue related to the deficiency. This is logically possible because, while the truth standards enhance reliability, the absence of one or more does not guarantee inaccuracy. In those presumably rare instances in which counsel believes that she can render a conclusion despite a failure to satisfy the truth standards, disclosure and explanation would be necessary. As we have noted, professional judgment requires investigative counsel to consider the effect of material limits on the reliability of her conclusions, and she has greater insight into their effect than the typical reader of the report. ${ }^{184}$ As a result, disclosure of the qualification is not enough. Counsel should identify the limits on the investigation and explain why her conclusions are reliable notwithstanding the deficiency. The reader, of course, may not be persuaded by the explanation, which is why investigators and clients would prefer to satisfy the truth standards.

A third possible consequence of the failure to satisfy the truth standards falls somewhere between the first two approaches. As a result of a deficiency in procedure, the investigator might reach a factual or legal conclusion with a lesser degree of certainty. Instead of a conclusion offered to a reasonable degree of professional certainty or some comparable formulation, ${ }^{185}$ the investigator might offer a conclusion but state that it is "tentative" or offer some other formulation that reflects the investigator's diminished confidence in the reliability of the investigation ("reduced-confidence standard"). Because readers may not understand the reduced-confidence standard, the investigator should explain its significance. The investigator should also identify the truth standard(s) not satisfied (or other material limitations) and describe any effect on the investigator's fact-finding and conclusions. The investigator and her client have every reason to satisfy the truth standards because a report claiming a lesser standard of confidence in the outcome is less likely to warrant reliance by the recipient, whether a third party or client. ${ }^{186}$

An investigator may be unable to satisfy the truth standards not only because the client has barred access to important information or has otherwise refused to cooperate, but also because of conditions beyond the control of the client or investigator ("external limitations"). For example, a material witness may be deceased, unavailable for health reasons, or uncooperative; critical documents may have

184 See supra Part III.D.

185 See supra Part III.C.

${ }^{186}$ See supra Part II.A.3 (discussing the nature of the client and third party reliance on the report). 
been lost prior to the investigation; or the exigency of the report may limit the extent of the inquiry. The client may wish counsel to proceed nonetheless, since the client's various motives for commissioning an internal investigation are generally unrelated to the presence or absence of external limitations. ${ }^{187}$ Investigative counsel may be more willing to conduct an investigation when the material limitations are external rather than client-imposed because the difficulties are legitimate rather than contrived and a report, despite such limitations, may be as close to the truth as practical.

Nevertheless, while external limitations are not the result of client manipulation, they do not excuse counsel from exercising professional judgment to assess their effect on the reliability of the investigation. ${ }^{188}$ In the face of external limitations, investigative counsel should disclose the material qualifications; determine whether they allow or preclude findings and conclusions, or warrant a reducedconfidence standard; and, in any event, explain their effect on reliability. The report recipient presumably will be more tolerant of external limitations because the investigator's attempt to find the truth may be the best account possible in trying circumstances.

\section{E. Transparency}

As we have discussed, a critical component of the investigator's role is the exercise of professional judgment in interpreting and applying the law. Although professional judgment shapes and constrains the investigator's interpretive efforts, the interpretive range of this standard allows room for disagreement. In other words, investigators, just like judges, can reach differing outcomes when confronted with the same facts and legal standards, and differing interpretations can both be legitimate in the sense that they are within the canons of professional interpretation. ${ }^{189}$ All of this should pose troubling questions for the recipient of the investigative report. Except in the most obvious and determinate legal circumstances, the investigator's conclusions likely require interpretation and application of legal standards that cannot purport to be definitive. Moreover, while fact-

${ }^{187}$ See generally supra Part II (identifying and categorizing client motives for commissioning an internal investigation).

188 Model Rules of Prof'L Conduct R. 2.3 cmt. 4 (2007).

189 See supra notes 112-16 and accompanying text. In fact, Owen Fiss contends that a decision that is within the boundaries of professional judgment can still be wrong even though it is not illegitimate. Fiss, supra note 117, at 748 ("Just as objectivity is compatible with a measure of disagreement, it should also be stressed that objectivity is compatible with error: [a]n objective interpretation is not necessarily a correct one."). 
finding is constrained by the investigator's commitment to accuracy and the application of the truth standards, it also has an interpretive and professional-judgment component. ${ }^{190}$ Thus, even if the report recipient can safely presume that the investigator has exercised sound professional judgment, why should she accept the investigator's conclusions?

The answer, put bluntly, is that the reader should not rely on the investigator's conclusions alone. ${ }^{191}$ The report recipient must examine the analysis and interpretation that gave rise to those conclusions-not only to confirm that they are grounded in sound professional judgment, but also to determine whether the report recipient agrees with the investigator's interpretive efforts. The value of the investigative report lies not only in its commitment to the truth standards and professional judgment, but in its detailed explanation of the evidence, reasoning, and interpretation that gave rise to the conclusions. ${ }^{192}$

For this reason, the investigator will devote considerable effort to developing a full account of the reasoning that underlies the report's conclusions. A report that offers only conclusions or only a cursory account of their basis is of minimal value to the report recipient. A conclusory report asks the report recipient to accept the investigator's interpretation at face value. Why should a report recipient accede as much, when judges - who are not compensated by clients for their investigative efforts-regularly disagree about the meaning and application of the law?

\section{F. The Truth Standards and Negligence}

The truth standards developed herein are not grounded on tort principles; they derive from the accuracy commitment implied by the attorney-ethics rules in reliance investigations and by the duty of inquiry imposed on corporations in a variety of settings. ${ }^{193}$ Nonetheless,

190 See supra notes 98-101 and accompanying text; Part III.B.4.

191 In the case of an investigative report submitted to the client to satisfy a duty of inquiry, the board of directors or appropriate client entity is charged with forming conclusions and thus should not blindly accept the investigator's findings and conclusions, but should instead reach its own conclusions based on the information presented. See ReCOMmended Practices, supra note 82, at 496.

192 See Wendel, supra note 114, at 1190 ("In every serious account of legal interpretation, the interpreter's judgment must be transparent- that is, available for public observation and criticism. Requiring the interpreter to justify her judgment to the public defends the judgment's objectivity against the critique that the interpreter is simply imposing her own policy preferences on the law.”).

${ }_{193}$ See supra Part III.A.1. 
investigative counsel does owe a duty of care under negligence law to the client and the third party to whom she delivers a report. ${ }^{194}$ But the duty of care standard leaves critical questions unanswered. First, what is the content of the duty? Second, how can duties of care owed to a third party be squared with investigative counsel's duty of care to the client? ${ }^{195}$

The truth standards suggest answers to both questions. They describe with some precision the duties of counsel who conduct duty and reliance investigations. In a reliance investigation, they identify what the third-party recipient of the report has a right to expect and rely on: an investigation committed to developing an accurate account by adherence to the truth standards that further such goal. Likewise, a client who commissioned such an investigation to satisfy a Sarbanes-Oxley inquiry duty (or to satisfy management's duty of care) should expect that each of the truth elements will be satisfied by counsel and that client can therefore rely upon the resulting investigation to fulfill its own inquiry requirements.

In addition, a central question in the reliance investigation is how the investigator's duties to a third party can be squared with the investigator's obligations to the corporate client who commissions, underwrites, and is the subject of the investigation. Without reference to the truth standards, negligence law offers no principled basis for reconciling the duties of care to the client and the third party because it simply extends a general duty of care to both parties. ${ }^{196}$ The truth standards offer a clear conception of how to reconcile the competing roles of investigative counsel that can answer such questions in the tort setting. Investigative counsel cannot be held liable to the client or a third party for acts or omissions that are required by the truth standards, even though the report may disserve either party's interests. ${ }^{197}$

194 Restatement (ThiRd) OF THE LAW GOVERning LAWYERS $\$ 95 \mathrm{cmt}$. a (2000); RESTATEMENT (SECOND) OF TORTS $§ 552(1)$ (1977) (identifying an exception not relevant here).

${ }^{195}$ See generally Kevin H. Michels, Third-Party Negligence Claims Against Counsel: A Proposed Unified Liability Standard, 22 GEO. J. LEGAL ETHICS 143 (2009) (arguing that the principal limitation on attorney duties of care to third parties should be the attorney's conflicting ethical obligations to clients and others).

${ }^{196}$ See supra note 194 and accompanying text.

197 See Restatement (ThIRD) OF THE LAW GOVERning LAWYERS § 54(1) (providing that duty of care does not require an attorney to perform any act in violation of an ethical duty). 


\section{THE TRUTH STANDARDS APPLIED}

The next question is what the truth standards signify for practitioners in the investigation setting. We will examine each phase of the investigation process from retention to the investigation itself to reporting, asking how the truth standards and other insights offered in Part III shape the practice of counsel who conduct internal investigations. ${ }^{198}$ The practice issues that follow are selective rather than exhaustive; the main objective is to refine an understanding of the truth standards through application.

\section{A. The Retention Structure}

When the corporation decides to undertake an internal investigation, it retains counsel who will conduct the investigation. By retains or retention, we refer to the engagement agreement to undertake an internal investigation between the corporation and counsel. ${ }^{199}$ The investigating attorney serves as counsel to the corporation, not to any of the other stakeholders in the investigative outcome. ${ }^{200}$ The investigation often entails the collection and preservation of relevant documents and data; identification and interviewing of witnesses; development of a factual and legal analysis; and an oral or written report to the company, which explains what happened and its legal significance. ${ }^{201}$

The client who retains and compensates investigative counsel understandably expects a certain degree of control over the effort. Both client and counsel must therefore understand and agree on the nature of the counsel's investigative role and the limits on the client's control over the investigation. The corporation and investigative counsel should expressly agree that counsel is charged with producing an accurate account in accordance with truth standards, and that

198 The analysis that follows presumes that the truth standards apply to the investigation in question. The truth standards apply to most investigations that are conducted in response to material allegations of wrongdoing. See supra Part II.B.

199 Although the Model Rules indicate that it is preferable to communicate the retainer agreement in writing, Model Rules OF PROF'L CONDUCT R. 1.5(b) (2007), certain states require a retainer agreement to be in writing. See, e.g., ARIz. RulEs of Prof'l Conduct R 1.5(b) (2004); Colo. Rules of Prof'l Conduct, R. 1.5(b) (2008); Conn. Rules of Prof'l Conduct, R. 1.5(b) (2007); N.J. Rules of Prof's Conduct R. 1.5(b) (2009). Given the importance and complexity of the undertaking, internal investigations should be conducted only pursuant to a written retainer agreement.

200 See Model Rules of Prof'l Conduct R. 1.13(a).

201 For an overview of the investigative process, see Duggin, supra note 2, at 89092; Collin P. Marks, Thompson/McNulty Memo Internal Investigations: Ethical Concerns of the "Deputized" Counsel, 38 ST. MARY's L.J. 1065, 1068-71 (2007). 
the client will impose no limitations on counsel that will prevent her from fulfilling this objective. Beyond this general understanding, counsel and client should be sensitive to an array of issues that arise in the retention stage, from assurance that conflicts of interest will not undermine the investigation to the grant of sufficient latitude to conduct an investigation that satisfies the sufficiency standard. We will consider these issues next.

\section{The Biasing Interest}

Biasing interests are interests, incentives or obligations of investigative counsel that pose a substantial risk of materially diverting the investigator from providing an accurate account. ${ }^{202}$ Client compensation of the investigator, standing alone, does not present an interest that diverts investigative counsel from seeking an objective account in the way that other biasing interests discussed below may. ${ }^{203}$ When, however, the investigating attorney serves as counsel to the corporation in connection with matters other than the investigation, the attorney has a financial incentive to render a report that is not damaging to the corporation, because a harmful report may result in the loss of future work on behalf of the client. ${ }^{204}$ In Enron, for example, the court rejected a motion to dismiss claims against the law firm that conducted the internal investigation, citing its receipt of over $\$ 100$ million in legal fees from Enron on other matters; the fact that Enron was the firm's largest client, representing seven percent of the firm's revenue; and the fact that, over the years, more than twenty of the firm's attorneys left to join Enron's in-house legal department. ${ }^{205}$

202 See supra Part III.

203 Cf. MOdel Rules of Prof'L Conduct R. 2.3(a) (contemplating such compensation for an evaluation through use of the term "client"). Likewise, in the clientrepresentation setting, the Model Rules expressly allow third-party payment of a client's legal fees, provided inter alia that there is "no interference with the lawyer's independence of professional judgment." Id. R. 1.8(f). The analogy from the representation to the investigation context is helpful, although the roles are in a sense reversed: the client can be understood as paying for the legal services involved in developing an accurate account for itself and the third-party recipient of the report, and the client's payment for such services must not affect the professional judgment of the investigator.

204 See James D. Cox, Managing and Monitoring Conflicts of Interest: Empowering the Outside Directors with Independent Counsel, 48 VILL. L. REV. 1077, 1085 (2003) (noting that in the special litigation committee context "the committee's counsel's ability to retain future corporate business is dependent upon the decisions of the very executives the committee, through its counsel, is investigating").

${ }^{205}$ In re Enron Corp. Sec., Derivative \& "ERISA" Litig., 235 F. Supp. 2d 549, 65657 (S.D. Tex. 2002). For an example in the shareholder derivative setting, see In re Par Pharm., Inc. Derivative Litig., 750 F. Supp. 641, 647 (S.D.N.Y. 1990) (refusing to 
Another important question is whether the company's in-house counsel can conduct an internal investigation. The in-house attorney has even stronger financial ties to the corporation than longstanding outside counsel because the company is the source of her employment and salary. ${ }^{206}$ A report that finds the corporation or its management guilty of criminal or civil wrongdoing is not likely to enhance the employment prospects of the general counsel. Another concern posed by such an arrangement is the prior relationship between management of the corporation and general counsel, which may add a personal element to an investigative role that is already fraught with the potential for conflict. ${ }^{207}$ Once again, as with all biasing interests, general counsel may rise above these personal concerns and present an accurate account. In-house counsel, for example, regularly advise their executives not to press forward with transactions despite the disfavor they may incur for such advice. In fact, the ability to render honest, dispassionate advice, favor notwithstanding, likely ranks among the higher callings of inside counsel when advising the corporation. One commentator argues that the decision regarding whether to use in-house counsel or special counsel is "far more nuanced than is often appreciated," citing considerations that include access to corporate information and its relation to a corporation's business, and attorney-client privilege and work product concerns. $^{208}$

The bias element of the independence standard does not warrant a per se prohibition on an internal investigation by inside counsel, except when the statute or court rules insist on such complete separation. $^{209}$ On balance, however, inside counsel faces a considerable

dismiss action, citing special litigation committee's failure to retain independent counsel). For instances outside the investigation context in which a prior or ongoing relationship with the client has been questioned, see 17 C.F.R. $\$ 270.0-1$ (a) (6) (i) (A) (2002) (construing Investment Company Act of 1940, which requires approval of independent directors advised by independent counsel before undertaking certain transactions); Cox, supra note 204, at 1085 (arguing that counsel who advise independent directors on whether to approve transactions that pose conflicts of interest for management should not have prior relationship with company).

206 See Deborah A. DeMott, The Discrete Roles of General Counsel, 74 FORDHAM L. REv. 955, 956, 967-68 (2005); $\quad$ E. Norman Veasey \& Christine T. Di Guglielmo, The Tensions, Stresses, and Professional Responsibilities of the Lawyer for the Corporation, 62 Bus. LAW. 1, 11, nn.27-28 (2006).

207 See, e.g., Bennett v. Progressive Corp., 225 F. Supp. 2d 190, 211 (N.D.N.Y. 2002); Hill v. Children's Vill., 196 F. Supp. 2d 389, 396 (S.D.N.Y. 2002).

${ }^{208}$ Sarah Helene Duggin, The Pivotal Role of the General Counsel in Promoting Corporate Integrity and Professional Responsibility, 51 ST. LouIs U. L.J. 989, 1008 (2007).

${ }^{209}$ The shareholder-derivative action, for example, requires outside counsel. Dalrymple v. Nat'l Bank \& Trust Co. of Traverse City, 615 F. Supp. 979, 986 (W.D. Mich. 
burden in showing that the advantages of the experienced insider outweigh the bias concerns posed by inside counsel's ongoing employment. When corporate counsel advises the company not to go forward with a transaction despite the profit potential, it is often because she sees a more important long-term corporate interestliability or a regulatory concern, for example-at stake. Thus, the candor that accompanies unpopular advice is typically consonant with the interests of the corporation. By contrast, an investigative report that concludes that the company or its senior management is guilty of civil or criminal wrongdoing portends material adverse consequences to the company, which is sharply distinct from negative advice that will benefit the corporation in the long run. Moreover, inside counsel need not personally conduct the internal investigation in order to share his business background, personnel, and contextual knowledge with investigative counsel. With respect to witness access, the corporation can generally condition continued employment on cooperation with the investigation, ${ }^{210}$ a resource that should be at least as strong as friendship in encouraging cooperation. ${ }^{211}$ And finally, as discussed earlier, we restrict material biasing interests not because they are guaranteed to skew the investigation but because the recipient of the report has no way to determine whether bias affected the outcome. ${ }^{212}$

Another source of bias relating to the role of counsel concerns the risk that counsel will investigate issues on which the attorney pre-

1985) ("The role of the Special Litigation Committee is anomalous, as it involves an ostensibly independent investigation by directors of their colleagues' and their own, misconduct, assisted by an attorney selected precisely because he had no previous professional relationship with either the corporate entity or its directors. Problems of conflicting loyalties in connection with previous transactions and advice given to the corporation and its managers do not, therefore, arise.”). A Sarbanes-Oxley investigation should also be conducted by outside counsel. Former SEC Commissioner Cynthia A. Glassman has encouraged independence "in definition as well as spirit." Glassman, supra note 66.

210 See Michael Waldman, Internal Investigations for Government Contractors, in INTERNAL CORPORATE INVESTIGATIONS, supra note 12, at 335, 406-07.

${ }^{211}$ Moreover, if the witness's longstanding relationship with inside counsel would prompt the witness to repose trust in counsel qua investigator, then counsel may be trading unfairly on such trust, given that investigative counsel represents only the corporation (and not the witness) and that the corporation may later decide to disclose the report notwithstanding its inculpation of the witness. See Duggin, supra note 2, at 910-11; see also MODEL Rules OF PROF'L CONDUCT R. 1.13(f) (2007) (requiring a lawyer, when "dealing with an organization's directors, officers, employees, members, shareholders or other constituents," to "explain the identity of the client when the lawyer knows or reasonably should know that the organization's interests are adverse to those of the constituents with whom the lawyer is dealing").

${ }^{212}$ See supra notes 131-41 and accompanying text. 
viously had a counseling role. The conflict here stems from the fact that the attorney has a personal interest in affirming the propriety of the act or omission on which she gave advice, given that a contrary assessment might expose her to a malpractice or third-party claim. The now archetypal example of this conflict is Enron, in which the law firm investigated the propriety of transactions that it earlier handled or for which it earlier acted as counsel. ${ }^{213}$

\section{The Advocacy Conflict}

The retention agreement should make clear that the investigator is not, in any sense, a client advocate and that the investigator has no obligation to protect or advance the interests of the client in connection with the investigation. As discussed earlier, the defense of the corporation on charges related to the investigation poses a direct conflict with the investigative role, and thus the truth standards ban an investigating attorney from also acting as defense counsel in an action related to the investigation. ${ }^{214}$

Suppose that in addition to the investigative role, counsel is retained to advise the corporation on whether and how to disclose the report to the government, and to assist the corporation in gaining the best possible outcome in a negotiation with the government. Here, the line separating the investigative and advocacy roles is dangerously blurred. The investigator has a dual commitment: to develop an accurate account for the third party and the corporation and to minimize the company's exposure with respect to the subject of the investigation. This tension can undermine the investigation. ${ }^{215}$

When responding to allegations of wrongdoing, corporations have an incentive to identify evidence proving that the criminal

${ }^{213}$ In re Enron Corp. Sec., Derivative \& "ERISA" Litig., 235 F. Supp. 2d 549, 63637 (S.D. Tex. 2002) (stating that investigative counsel "issued a whitewash report dismissing these detailed complaints of fraud even though the law firm knew the allegations were true because it was involved in structuring many of the manipulative devices"); see also Cramton, supra note 29, at 164-66 (2002) (noting conflict posed by investigative counsel's investigation of transactions that counsel helped consummate).

214 See Restatement (ThiRd) OF THE LAW GOVERning LaWYers § 95 cmt. c (1998).

215 Consider, for example, the mixed investigative and advocacy role described in Bennett, supra note 12, at 57 (2007). The article examines investigations designed to "protect the interests of the corporation. ..." Id. It later discusses whether and how the investigation results should be disclosed to the government to gain cooperation points and defuse potential criminal prosecution. Id. at 80-84. To the extent, however, that the investigation itself is shared with the government or another third party, the truth standards apply and prevent assumption of a corporate protection or defense role by investigative counsel. 
wrongdoing was the isolated work of lower-level employees and was not orchestrated at the executive or policy level, because the latter will result in more severe corporate sanctions. ${ }^{216}$ Given the risks that the discovery and disclosure of such inculpatory information pose, the attorney who is charged with both conducting the investigation and with an advocacy role with respect to its disclosure may face conflicting incentives when the investigation suggests management-level wrongdoing. How energetically will investigative counsel, who is also charged with advancing the corporation's interests, pursue and develop inculpatory evidence when the results of that investigation may expose the corporation to grave economic and criminal consequences? A vigorous, company-sponsored search for facts and information showing management-level complicity or reckless indifference in such criminal wrongdoing is hardly the self-evident first step in protecting the corporation's interests. Even more delicate questions would surround investigative counsel's characterization of the facts in the investigative report if the investigator also assumed such an advocacy role. Therefore, investigative counsel should make clear in the retention agreement that she will not assist in seeking to optimize the outcome for the corporation in its dealings with third parties with respect to the investigation issues, even though the investigation and advocacy roles are separated temporally. ${ }^{217}$ This is one reason why it is critical to identify which investigations are subject to truth standards; in a reliance or duty investigation (as distinct from a counseling investigation), this advocacy role is simply unacceptable. ${ }^{218}$

216 All too often legal and social responsibility and blame is attributed to individuals, often relatively junior individuals, who may have been the immediate cause of a corporate misdemeanours [sic], rather than attention and responsibility being attributed to the structural and systemic problems which may have given rise to or allowed the problem to emerge.

Bridget M. Hutter, Structure Model: Reforming Regulation, in Debating Corporate CRIME 208 (W.S. Lofquist et al. eds., 1997); see also Laufer, supra note 7, at 658-59 (discussing the dangers of scapegoating lower-level employees).

217 In addition, investigative counsel should not later represent the client with respect to issues relating to the investigation in a civil or criminal matter. RECOMMENDED PRACTICES, supra note 82, at 496.

${ }^{218}$ Professor Duggin argues that in order to fulfill his ethical duty to the corporation, an investigator must search for and develop evidence of lower-level wrongdoing, since the latter will minimize the corporation's culpability. Duggin, supra note 2 , at 910 . Although it is one of the finest pieces of scholarship to date on internal corporate investigations, the article, like most others, does not seek to identify which investigations are subject to truth standards or what those truth standards entail. Id. passim. It is a central claim of this Article that in a reliance or truth investigation it is avowedly not the obligation of counsel to protect the corporation's interest. On the contrary, investigative counsel's role is to develop an accurate account. 
Investigative counsel should resist assuming all duties that blur the line between investigator and advocate. Counsel charged with optimizing the outcome for the client are simply not in a position to develop an accurate assessment of the company's wrongdoing. Other advocacy conflicts can arise when counsel assumes, on behalf of the client, a role related to the investigation that has the potential to undermine the truth standards. In Part IV.B, we will discuss how investigative counsel's efforts to protect the attorney-client privilege during the course of the investigation can affect the truth standards.

\section{The Sufficient-Inquiry Standard}

Counsel and client should also agree at the retention stage that counsel will have ample latitude and resources to conduct an investigation that satisfies the sufficiency standard. The client, of course, has a legitimate interest in ensuring that the cost of the investigation is reasonable. ${ }^{219}$ What is reasonable, however, is based on the time and resources necessary for counsel to conduct a sufficient inquiry as defined above. ${ }^{220}$ The corporation should agree to provide access to documents, employee witnesses and other sources within its control that will enable counsel to conduct a sufficient inquiry. Additionally, the investigator can accept no client-expenditure or access limits that preclude sufficient inquiry.

The sufficient-inquiry standard likewise requires agreement at the retention stage on the issues counsel will investigate. At first blush, one might assume that the allegation of wrongdoing that triggers the internal investigation would define the issues to be investigated. This presupposes, however, that the allegation is sufficiently crafted to identify such wrongdoing. In fact, credible allegations can arise from current and former employees, customers, or others who may not have the legal background to understand or articulate the nature of the wrongdoing. Moreover, the complainant may not be privy to the full extent of the wrongdoing and the allegation may identify only a small aspect of a larger problem.

Despite these difficulties, counsel and the corporation should seek in the retention agreement to describe the problem to be investigated with sufficient breadth to ensure that the investigator has the

219 Cf. Model Rules of Prof'l Conduct R. 1.5(a) (2007) (“A lawyer shall not make an agreement for, charge, or collect an unreasonable fee or an unreasonable amount for expenses.”).

220 See supra Part III.B.2. 
authority to explore the issue in its entirety. ${ }^{221}$ Conversely, there is danger in describing the issue more expansively than the parties intend because the commitment to accuracy precludes counsel from delivering an investigative report that explores less than the issue it purports to examine. Of equal importance, the retention agreement should establish a procedure whereby counsel can expand the scope of inquiry during the course of the investigation, should it be warranted. ${ }^{222}$

\section{B. Conducting the Investigation}

In this Part, we will consider two questions that require the close attention of counsel during the course of an investigation. The first concerns a question that often cannot be fully answered until after the investigation is underway: what issue will counsel investigate? The second concerns the delicate handling of privilege questions during the course of the investigation.

\section{Scope and Depth}

The factual component of the investigation might be parsed into two categories: "scope" and "depth." "Scope" might be visualized as a horizontal line representing the range of factual events and issues that counsel will explore. "Depth" might be represented by a vertical line, representing the extent of the inquiry on any given fact question or issue. The accurate account and sufficient-inquiry standards require counsel to keep a close watch on each of these two aspects of the factual inquiry.

With respect to scope, counsel may discover during the investigation that the alleged problem is just one instance of a larger array of wrongdoing. Counsel must then explore with the client whether the scope of the investigation should be expanded to reflect that discovery. The client may have mixed feelings about such an expansion. The client may be concerned about increasing the expense and intrusiveness of the investigation and the corporation's exposure. Nevertheless, the client should also understand that ignoring internal wrongdoing may present graver risks.

${ }^{221}$ For examples in the shareholder derivative setting, see Electra Inv. Trust PLC v. Crews, No. 15890, 1999 WL 135239 (Del. Ch. Feb. 24, 1999) (requiring thorough investigation); Auerbach v. Bennett, 393 N.E.2d 994, 1000-03 (N.Y. 1979) (discussing the insufficiency of limited or pro forma investigations).

${ }^{222}$ See infra Part IV.B.1 (discussing scope changes during the course of the investigation). 
Investigative counsel faces a different set of concerns. First, counsel should not advise a company as to how a change in scope could affect its culpability because such an advisory role conflicts with the attorney's investigative role. ${ }^{223}$ The attorney, however, is not indifferent about whether to expand the scope of the investigation because the question bears directly on whether the investigation will satisfy the truth standards. Under the sufficient-inquiry standard, the attorney must inquire into the facts of the allegation until additional investigation no longer presents a genuine prospect of gaining information that will materially affect his findings on the issue in question. $^{224}$ If that issue involves more departments and personnel than originally anticipated, or if the wrongdoing is part of a scheme that extends more broadly than expected, then the scope of the investigation must be expanded so that the issue can be sufficiently investigated and accurately reported. In a sense, the scope of the investigation is an ongoing question; sufficiency is in part a function of what is learned during the investigation about the range of involvement. ${ }^{225}$ If the client refuses to expand the scope of the investigation when the sufficiency standard demands such an expansion, then investigative counsel cannot deliver a report consistent with the truth standards.

The depth of the investigation implicates the evidentiaryreliability standard. The case law and ethics opinions that consider opinion letters offer important insight as to what is required of the attorney. ${ }^{226}$ The attorney may not rely on statements of company officials if the information "appears irregular on its face or has been provided by an inappropriate source." ${ }^{227}$ One ABA opinion identifies an array of reasons to look beyond an officer's assertion, stating, "If any

223 See supra note 128 and accompanying text.

224 See supra Part III.B.2.

${ }^{225}$ A retention letter could allow counsel to expand the scope of the investigation on her own initiative, as necessary to ensure compliance with the truth standards. If the client prefers to be consulted prior to expansion of the scope, however, counsel can agree to do so, subject to the truth standards. Counsel cannot deliver a report if a client-imposed limitation on the scope precludes a sufficient investigation of the issue addressed. Pursuant to Rule 1.16(a) (3) of the Model Rules of Prof'l Conduct, the client has an unfettered right to terminate the investigative effort whenever it wishes, which is the client's principal protection if it perceives that the investigator is abusing his discretion or that the investigation is too costly. See Model RUles of Prof'L CONDUCT R. 1.16(a) (3) (2007).

${ }^{226}$ As noted earlier, opinion letters pose fewer concerns about reliability than internal investigations. See supra note 58 and accompanying text. Opinion letters do pose an attenuated version of the question at issue here, however: can investigative counsel rely on the statements of executives without inquiring further?

${ }^{227}$ ABA Comm. on Legal Opinions, Legal Opinion Principles, 53 Bus. LAw. 831, 833 (1998). 
of the alleged facts, or the alleged facts taken as a whole, are incomplete in a material respect; or are suspect; or are inconsistent; or either on their face or on the basis of other known facts are open to question, the lawyer should make further inquiry.”228 A source of suspicion prompting an opinion giver to inquire may be the client's "reluctance to disclose information." ${ }^{229}$ When the lawyer asked to deliver an opinion concludes, despite the need for further inquiry, that such investigation will not give him "sufficient confidence as to all the relevant facts," he should not deliver the opinion. ${ }^{230}$

These principles apply with greater force in the internal investigation setting. Because the allegations of corporate wrongdoing in the internal investigation context often pose substantial criminal and civil risks for the company, there is reason for concern that at least some of the actors in the corporation will be less than forthcoming. In the opinion context, the corporate employee will have fewer reasons to dissemble because the representations in the opinion letter provide assurances to consummate a transaction rather than an assessment of an allegation of wrongdoing. The internal investigation is truth seeking unlike any other in the American justice system. It is avowedly not adversarial. Truth does not emerge from the clash of positions, but from the unilateral inquiry of counsel. The investigator must, for example, consider witness demeanor, credibility, and candor; press witnesses in light of other contradictory testimony or documentation; determine when and whether to dig deeper with a particular witness; determine whether to search for other witnesses who can fill in gaps, reveal inconsistencies, affirm the testimony of others; and so on.

\section{Privilege}

Investigative counsel may be asked to investigate the corporation and to take steps to ensure that the corporation's attorney-client pri-

${ }^{228}$ ABA Comm. on Ethics and Prof'l Responsibility, Formal Op. 335 (1974).

${ }^{229}$ Id.

${ }^{230} I d$.

${ }^{231}$ See In re Enron Corp. Sec., Derivative \& "ERISA" Litig., 235 F. Supp. 2d 549, 668 n.103 (S.D. Tex. 2002) (quoting Roger C. Cramton, Enron and the Corporate Lawyer: Professional Responsibility Issues, 1324 PLI/CORP. 841, 854 (2002), reprinted in Cramton, supra note 29, at 164). The decision quoted Professor Crampton's criticism of the investigation for interviewing "only seven high-level officials, most of whom were directly implicated in the self-dealing and fiduciary violations raised by the Watkins allegations." $I d$. The investigator relied on the denials of these officials and did not interview nine other, lower-ranking employees whom one of the high-level officials identified as "good sources of information concerning Fastow's self-dealing." Id. 
vilege and work-product protections are maximized. ${ }^{232}$ By preserving the attorney-client privilege in the investigation, the company hedges its bets; the decision to disclose can be made after the investigation is complete, with the added benefit of knowing what independent counsel has discovered. On the one hand, an investigator's privilege maintenance does not imply a client commitment with respect to the outcome of the investigation. Therefore, counsel's efforts to protect the privilege are not inherently inconsistent with her accuracy obligation; in fact, an accurate account is the central rationale for providing corporations privilege protection in the investigation results. Corporations are more likely to undertake a free and open investigation into wrongdoing if they can maintain the results in confidence. ${ }^{23}$

Nonetheless, investigative counsel cannot allow efforts to protect the privilege to compromise her obligation to produce an accurate account. Investigative counsel often conduct their investigations on the assumption that their report and notes will be disclosed to prosecutors and adversaries. ${ }^{234}$ Although the disclosure may be voluntary to serve the cooperation goals, ${ }^{235}$ the prospect of such discovery can affect the truth-seeking efforts of investigative counsel. For example, some commentators advise investigative counsel to avoid taking verbatim transcripts of interviews during the investigation because purely factual recitations are more likely to be discoverable than memoranda summarizing interviews that contain "observations and opinions" of counsel. ${ }^{236}$ An investigator who is concerned solely with developing the most accurate account of what happened may well prefer a verbatim transcript of her discussions with dozens of witnesses rather than summaries laced with work product designed to

${ }^{232}$ In a reliance investigation, counsel may seek to preserve the attorney-client privilege and preserve the option for the company to decide after completion of the investigation whether to disclose it to third parties. See supra note 18 . In a duty investigation, the prospects of preserving the attorney-client privilege are reduced. See supra note 75 .

${ }^{233}$ See Upjohn Co. v. United States, 449 U.S. 383, 390-91 (1981).

${ }^{234}$ Due to the frequency of waiver demands, investigative counsel often "begin their investigations knowing that everything they discover, every note they take, and every interview they conduct will be reviewed by the DOJ and federal prosecutors." Marks, supra note 201, at 1079-80 (citation omitted).

See supra notes 47-57 and accompanying text. The Justice Department typically views such disclosure as evidence of company cooperation, which can substantially influence its charging and resolution decisions. See McNulty Memorandum, supra note 52, at 10 (prosecutors "may always favorably consider a corporation's acquiescence to the government's waiver request").

${ }^{236}$ Shapiro, supra note 49 , at 501 . The theory is that memoranda that are purely factual are less easily protected against discovery than those laced with attorney work product because the latter receives higher protection against discovery. 
reduce its discoverability. Moreover, investigative counsel sometimes recommend taking no notes during witness interviews because of the risk that the government or a future adversary may discover the materials. $^{237}$ The procedure is unobjectionable but not easily reconciled with counsel's obligation to develop an accurate, reliable account for a third party. ${ }^{238}$ For a profession that has long insisted on verbatim transcriptions of testimony in depositions and at trial, insisting on the absence of a written record is a striking departure in the truthseeking function of the investigation. ${ }^{239}$

Privilege protection-like any ancillary client obligation undertaken by investigative counsel-can have a subtle effect on investigative counsel's role. Will an attorney hired to conduct an investigation and to remain mindful of the risks posed by disclosure of its findings pursue inculpatory information with the vigor of one who carries no such privilege-protection burden? The tension can be reconciled only if counsel stays vigilantly attuned to the investigation priority of developing and delivering an accurate account.

\section{Reporting the Results}

Assuming that counsel has delivered a report to the client that satisfies the truth standards, the next issues concern disclosure of the report to third parties. As a general matter, the client has no obligation to release the investigative report to third parties and may withhold its decision on whether to do so until after it has received and considered the investigative report. Investigative counsel generally may not deliver the report to anyone other than the client without the client's consent. ${ }^{240}$

If the corporation directs investigative counsel to deliver the investigative report to the government, the shareholders, the public, a court, or some other third party, then the investigation and report must satisfy the truth standards or address their absence through the

${ }^{237}$ Turk \& Miller, supra note 155 , at 108 n.7.

${ }^{238}$ In fact, Turk and Miller acknowledge that reflecting a witness's observations as accurately as possible while maintaining work-product protection in the memorandum "often involves two occasionally conflicting goals." Id. at 109.

239 See id. at 102-03 (stating that while a transcript is "likely to reflect the witness's statement more accurately than a memo would," it "would not be entitled to any work product protection").

240 See Model Rules of Prof'L Conduct R. 2.3(b) (2007) (requiring client consent before disclosure of an evaluation that is likely to materially and adversely affect the client's interests to a third party). 
appropriate combination of qualifications, explanation, or a reducedconfidence standard. ${ }^{241}$

The corporate client may wish to release the results of the report to the public but not disclose the detailed findings contained in the report due to privilege, self-incrimination, management, or other reasons. If the client asks counsel to disclose less than the entire report, ${ }^{242}$ counsel must act to ensure that the information released fairly and accurately describes the outcome. For example, if the summary states that the investigation found no company wrongdoing, and that statement is only qualifiedly correct, then counsel must instruct the client to include such qualifiers or withhold the summary.

In a reliance investigation, counsel owes duties to the third-party recipient of the report. ${ }^{243}$ As a result, the client's desire to control the flow of information cannot undermine counsel's obligations under the truth standards. The client can choose whether to release the report, but it cannot manipulate the contents of the information disclosed if the information is to be portrayed as the finding of investigative counsel. Therefore, counsel and the client may be best served by an agreement at the time of retention on how report disclosure will be handled. For example, the agreement might state that the client reserves the right to determine whether the report should be released to a third party but that investigative counsel shall have no obligation to release the report unless it is complete or is a counsel-approved summary. ${ }^{244}$ Moreover, the agreement could provide that the client will not release any information that it characterizes as the product of an internal corporate investigation unless the entire report or a

241 See supra Part III.D.

${ }^{242}$ Fundamental questions attend any effort to summarize an investigative report. Given the range of discretion involved in developing an account, the value of the report ultimately is not its conclusions alone but is instead the care and accuracy with which the facts and legal standards are determined, the extent to which they are supported by the evidence, and the quality of the reasoning on which the conclusions are based-all of which are exhibited in the investigative report and not the conclusions. While a summary is not inherently deceptive, recipients of such shorthand accounts can hardly be expected to treat the report with the same respect as a full account. See supra Part III.E (arguing that results alone are of minimal reliance value to the report recipient). Although clients would no doubt resist, a report summary could contain a warning of the dangers of reliance on investigation conclusions without an understanding of the professional judgment and analysis on which it is based.

${ }^{243}$ See supra Parts II.A.3.a, III.A.1.

244 Counsel should approve a summary only if it accurately portrays the findings, both affirmative and adverse, and contains the appropriate reliability qualifications. Likewise, recipients of such summary should ask whether it has been approved by investigative counsel who conducted the investigation. 
counsel-approved summary is released. The client could, however, be granted the right to release information from the report provided that such information is not characterized as the result of an internal corporate investigation.

The corporation may direct investigative counsel to provide it with only an oral report. ${ }^{245}$ While this is certainly not objectionable for the client's internal use, it sharply restricts the prospects of disclosure of the investigative report to third parties. An oral report likely cannot sufficiently capture the nuances and limitations to constitute an accurate account when delivered to a third party. Perhaps the best way to ensure compliance with the truth standards is to provide recipients of an oral summary with access to the report itself or a written summary that has been approved by investigative counsel.

\section{CONCLUSION}

We began this inquiry by identifying the unanswered questions or suspect assumptions about the investigative enterprise that have prevented commentators and courts from developing a systematic understanding of the truth commitment entailed in the internal investigation. By way of conclusion, we will revisit these issues.

At their core, the first three questions ask whether there is a principled way to distinguish those investigations that are subject to special truth standards. The taxonomy in Part II identifies two types of investigations that require imposition of special truth standards: the reliance investigation and the duty investigation. In the reliance investigation, which implicates the attorney-ethics rules, the investigator makes claims about the provenance of the information disclosed to a third party. The second category of investigation that warrants special truth standards is the duty investigation, in which the internal investigation is used to fulfill inquiry duties under the duty of care or a statutory-investigation requirement, such as Sarbanes-Oxley. Moreover, corporations may be best served by insisting on compliance with the truth standards even in investigations that are not for delivery to a third party or that are conducted to satisfy corporate duties of inquiry.

The next questions are what truth standards should be imposed on reliance and duty investigations and whether truth standards are even viable given the degree of judgment involved in conducting and reporting on an internal investigation. The substantive-truth com-

${ }^{245}$ Edwin G. Schallert \& Natalie R. Williams, Report of the Investigation, in INTERNAL CORPORATE INVESTIGATIONS, supra note 12, at 301, 303-04. 
mitment that attaches to both the reliance and duty investigation is accuracy. The third party in the reliance investigation and the corporation in the duty investigation rely on the investigative report because of its implied commitment to an accurate account. The investigative role is therefore distinguished principally by its commitment to the truth. The investigator does not communicate as a client representative, spokesperson, or advocate, nor does she offer opinion or conjecture; instead, she engages in fact-finding, legal research, and analysis designed to provide as nearly as practicable an accurate account of the facts, the legal standards, and conclusions of law.

The investigative goal of accuracy raises important questions about the objectivity of the law, facts, and their application in an internal investigation. Do these elements admit of accuracy in an objective sense, and how can the seemingly quixotic goal of accuracy be translated into a workable standard? The facts in an investigation approach the ideal of "strong" objectivity: they exist independently of the investigator's mind and of what anyone else believes about them. Law and its application are best understood as objective in the minimal sense; they exist independently of the investigator's mind, but they are constrained by the interpretive norms, standards, and principles of the legal community. While the opinion of the legal community may not be right in some ultimate sense, it is objective in the sense that it is both bounded and not based on the investigator's state of mind. For these reasons, the elements of an internal investigation are sufficiently objective for accuracy-properly understood-to serve as the goal of an investigation. In turn, the goal of accuracy warrants adherence to procedural standards that will enhance the prospects of an accurate account.

In Part III, we identified and described the four procedural elements-independence, sufficient inquiry, evidentiary reliability, and professional judgment - which substantially enhance the prospects of an accurate account when satisfied. Independence requires the avoidance of advocacy conflicts, which are client-advocacy functions relating to the conduct and report of the investigation, and biasing interests, which are interests, incentives, or obligations of investigative counsel that present a substantial risk of materially diverting the investigator from providing an accurate account. Despite the emphasis of lawmakers and courts, independence alone is not enough; it is only one of the procedural-truth standards that serve the core substantive standard of accuracy.

The sufficient-inquiry standard requires that counsel inquire into the facts of the allegation until additional investigation no longer 
presents a genuine prospect of gaining information that will materially affect the findings. The investigator must also conduct sufficient research to determine the legal standards implicated by the factual findings. The third standard, evidentiary reliability, requires that the investigator address the special concerns regarding the reliability of evidence that flow from the absence of adversarial or judicial checks on the investigative process. Under the final standard, professional judgment, counsel must interpret legal rules and standards in accordance with the norms, standards, and procedures accepted by the legal community. The call for professional judgment extends to interpretation of the other truth standards as well, which must be construed and applied in light of their principal purpose-to enhance the reliability of the investigation.

The truth standards and their rationale present a number of additional implications for the investigative enterprise. Although they cannot guarantee a correct outcome, the truth standards warrant imposition of a confidence standard resembling that applied to experts generally: the investigator must report results to a reasonable degree of professional certainty. When the truth standards are not satisfied, however, juxtaposing conclusions with qualifications is not enough. Instead, the investigator must determine whether conclusions are possible in light of the deficiencies, identify a standard that reflects the confidence one should have in the conclusions in light of the qualifications, and explain the effect on the qualifications of the investigation outcome.

The truth standards have two other important implications. First, the professional judgment required of the investigator, though it guides and constrains the investigator, leaves considerable room for interpretation and for disagreement within its legitimate boundaries. Therefore, the report recipient should be unwilling to rely on an investigative report that does not provide a detailed explanation of the evidence, analysis, and interpretation that gave rise to the outcomes. Second, the truth standards and related insights have important implications for the tort obligations of investigators because they inform the standard of reasonable care by detailing the investigator's obligations and their relation to client duties.

In application, as Part IV discussed, the truth standards shape and guide the role of the investigator. First, they allow investigators and clients to determine with some precision whether the investigation must or should be conducted in accordance with the truth standards. Second, the truth standards enable the investigator and client to identify their respective obligations in advance of the investigation 
and to design retention agreements to memorialize these commitments. Third, the truth standards will provide investigators with a deeper understanding of the nature and rationale of the truth commitment that their investigative effort entails, as well as a roadmap for conducting and reporting the investigation. This includes conflicts related to the investigator's own role, the scope and depth of their investigative duties, the adoption of methods to test the reliability of witness statements, and explanations to the report recipient of material concerns that affect accuracy. The truth standards also identify investigator commitments that can undermine the reliability of the investigation, which include acceptance of client-imposed scope and depth-of-inquiry limitations, privilege-protection efforts that can undermine reliability, the dangers of counseling the client on whether and how to share the investigation with third parties, and concerns about the release to third parties of information that inadequately summarizes the findings of the investigation.

The most valuable contribution of the truth standards lies elsewhere, however. Government officials, courts, shareholders, the public, and the corporation rely on investigative reports in assessing allegations of material wrongdoing against the corporation-matters of unquestioned importance to the corporation, its stakeholders, and society. The truth standards enhance the prospect that those who receive and rely on investigative reports will receive an accurate account. The stakes are too high to accept anything less. 